\title{
Carbon flow through the pelagic food web in southern Chilean Patagonia: relevance of Euphausia vallentini as a key species
}

\author{
H. E. González ${ }^{1,2, *}$, M. Graeve ${ }^{4}$, G. Kattner ${ }^{4}$, N. Silva ${ }^{5}$, L. Castro ${ }^{6,7}$, J. L. Iriarte ${ }^{2,3,7,8}$, \\ L. Osmán ${ }^{9}$, G. Daneri ${ }^{3,7}$, C. A. Vargas ${ }^{10}$ \\ ${ }^{1}$ Universidad Austral de Chile, Instituto de Ciencias Marinas y Limnológicas, Valdivia, Chile \\ ${ }^{2}$ Centro FONDAP de Investigación de Ecosistemas Marinos de Altas Latitudes (IDEAL), Universidad Austral de Chile, \\ Valdivia, Chile \\ ${ }^{3}$ Centro de Investigación de Ecosistemas de la Patagonia (CIEP), Coyhaique, Chile \\ ${ }^{4}$ Alfred Wegener Institute Helmholtz Centre for Polar and Marine Research, Bremerhaven, Germany \\ ${ }^{5}$ Escuela de Ciencias del Mar, P. Universidad Católica de Valparaíso, Valparaíso, Chile \\ ${ }^{6}$ Departamento de Oceanografía, Universidad de Concepción, Concepción, Chile \\ ${ }^{7}$ Centro COPAS-Sur Austral, Universidad de Concepción, Concepción, Chile \\ ${ }^{8}$ Universidad Austral de Chile, Instituto Acuicultura, Puerto Montt, Chile \\ ${ }^{9}$ The Nature Conservancy, Los Helechos 635, Valdivia, Chile \\ ${ }^{10}$ Departamento de Sistemas Acuáticos, Facultad de Ciencias Ambientales, Millennium Institute of Oceanography (IMO), \\ and Center for the Study of Multiple-Drivers on Marine Socio-Ecological Systems (MUSELS), Universidad de Concepción, \\ Concepción, Chile
}

\begin{abstract}
The southernmost Patagonian region constitutes a major glaciered area with a high freshwater input loaded with particulate and dissolved matter. We assessed the relevance of the terrestrial (allochthonous) and marine (autochthonous) matter that permeates into the fjord and channel system and their possible impact on the euphausiid-based food web. A research cruise (CIMAR 16) was conducted from 18 October to 13 November 2010 (austral spring) in the area between Magellan Strait and Drake Passage to study the physical-chemical and biological characteristics of the pelagic food web, as well as the main biological processes linked with the food web. The dominance of phytoplankton within the autochthonous fractions of particulate organic carbon (POC) and the high abundance and bacterivory rate shown by the heterotrophic nanoflagellates suggest an interplay between microbial and classical food webs. Euphausia vallentini showed a moderate grazing impact ( $3 \%$ of the gross primary production) and a daily ration of $18.6 \%$, and the fecal pellet production rate corresponded to $24.5 \%$ of the ingestion rate. This species removed heterotrophic prey $(67.5 \%)$ preferentially over diatoms $(32.5 \%)$, and the ingested diet was mainly dinoflagellates, tintinnids, crustacean nauplii and centric diatoms. Overall, euphausiids fed preferentially on marine matter, which showed a tight link with the pelagic food web. Congeneric species of the genus Euphausia shared the condition of 'key species' as they constitute a major carbon and energy flow from lower to higher trophic levels and an important part of the POC flux through their active vertical migration and passive fecal-carbon export.
\end{abstract}

KEY WORDS: Chilean Patagonia $\cdot$ Euphausia vallentini $\cdot$ Pelagic carbon flux $\cdot$ Euphausiid diet Resale or republication not permitted without written consent of the publisher

\section{INTRODUCTION}

Southern Chilean Patagonia is an entangled area of fjords and channels that receives a high volume of freshwater from river and glacial discharge. Overall, the freshwater is nutrient depleted (except of silicic acid), but very rich in total suspended particles and high in concentrations of particulate and dissolved 
organic matter (POM and DOM, respectively) (González et al. 2013). Thus, the cold and oligotrophic water of glaciers and rivers mixes with the nutrientrich Sub-Antarctic Water (SAAW) that penetrates the fjord region as part of the Antarctic Circumpolar Current(ACC). When the ACC approaches the coastal area of the southernmost part of Chilean Patagonia its name changes to Cape Horn Current, constituting one of the least studied systems in the eastern southernmost Pacific Ocean. The Sub-Antarctic system of the Magellan Strait and Cape Horn is unique because it is fed by one of the largest freshwater reserves on Earth (the North and South Patagonian Ice Fields), which is highly vulnerable to global warming (Rignot et al. 2003, Rivera et al. 2012). The presence of sill-constrictions has been mentioned as a key topographic feature in the regulation of water mass flow, which defines sub-basins within central (González et al. 2011) and southern (i.e. Strait of Magellan) Patagonian channels and fjords. The latter authors proposed dividing the Strait of Magellan into 3 basins: (1) from the Pacific entrance to Carlos III Island, an area dominated by Pacific SAAW, (2) from Carlos III Island to Segunda Angostura, an area dominated by a mixture of Pacific SAAW and glacial-fluvial freshwater and (3) from Segunda Angostura to the Atlantic entrance, an area dominated by Atlantic SAAW (Capello et al. 2011). These water masses set up a variety of biological, chemical and physical scenarios along west-east gradients in the study area (Mazzocchi et al. 1995). Thus, the mixture of terrestrial and oceanic environments inside fjords and channels affects the physical structure of the water column, setting a strong saline stratification that impinges on the structure and functioning of the pelagic and benthic ecosystems in southern Patagonia (Silva \& Palma 2008). For example, the presence of a strong pycnocline may function as a 'natural barrier' for the vertical distribution of plankton, affecting the vertical migration of zooplankton, e.g. the euphausiid species Euphausia vallentini. Also, the particle and particulate organic carbon (POC) export flux to the deeper layers of fjords and channels and to the sediments may be reduced.

The multiple origins of POM and DOM in southern Patagonia include input from terrestrial, riverine, estuarine and marine systems. These materials may subsidize the autochthonous production and enhance the microbial food web, particularly in winter (González et al. 2010, Vargas et al. 2012, Lafon et al. 2014), as a transition from large diatoms in spring to small flagellates in winter has been reported (Iriarte et al. 1993, Marino et al. 1993). Thus, a more complex trophic web (e.g. increase in mixotrophic nanoplankton, Czypionka et al. 2011) and a more conspicuous decoupling of the carbon export from the local primary production (PP) (González et al. 2013) may result from an exacerbated input of POC and dissolved organic carbon (DOC) of allochthonous origin.

The distribution of $E$. vallentini is circumglobal from the subtropical convergence from $\sim 38-42^{\circ} \mathrm{S}$ to the Polar Front at $\sim 60^{\circ} \mathrm{S}$ (or southern Cape Horn in the study area) (Antezana 1981). It is a key species and is the most abundant euphausiid in Chilean Patagonian waters (Palma \& Silva 2004), and constitutes an ecological bridge between microplankton and the upper trophic levels (i.e. fishes, penguins and whales). On an annual cycle, its feeding activity reaches the highest level from August to early October in the Southern Indian Ocean, which is concurrent with maturation and the beginning of its breeding season (Ridoux 1988). In addition, this species seems to play a pivotal role in the pelagic-benthic coupling through active (diel vertical migrations) and passive fluxes of carbon (i.e. production of fast-sinking fecal strings) (González et al. 2013).

The objectives of the present study were to study the overall biological, chemical and physical characteristics of the southern Patagonia region and to assess the concentration, provenance (allochthonous versus autochthonous) and distribution of the POC and DOC pools. In addition, the carbon export towards the sediments and its flow through the pelagic food webs will be assayed (with emphasis on the dominant euphausiid species E. vallentini) in the sub-Antarctic region of the Chilean Patagonia. We hypothesize that $E$. vallentini is an important member in this highly diverse environment, influencing the food web structure and the carbon flux. We focused our study on the most comprehensive transects in terms of spatial coverage (T2 and T5; Fig. 1), the Magellan Strait and the Beagle Channel-down to Cape Horn-as these are the transects that, through different disparate microenvironments, connect the Pacific and Atlantic Oceans.

\section{MATERIALS AND METHODS}

Samples were collected during the CIMAR 16 research cruise, which took place during austral spring, from 18 October to 13 November 2010, on board the RV 'Abate Molina' in the area between Magellan Strait and the Drake Passage (Fig. 1). Two research approaches were implemented. 


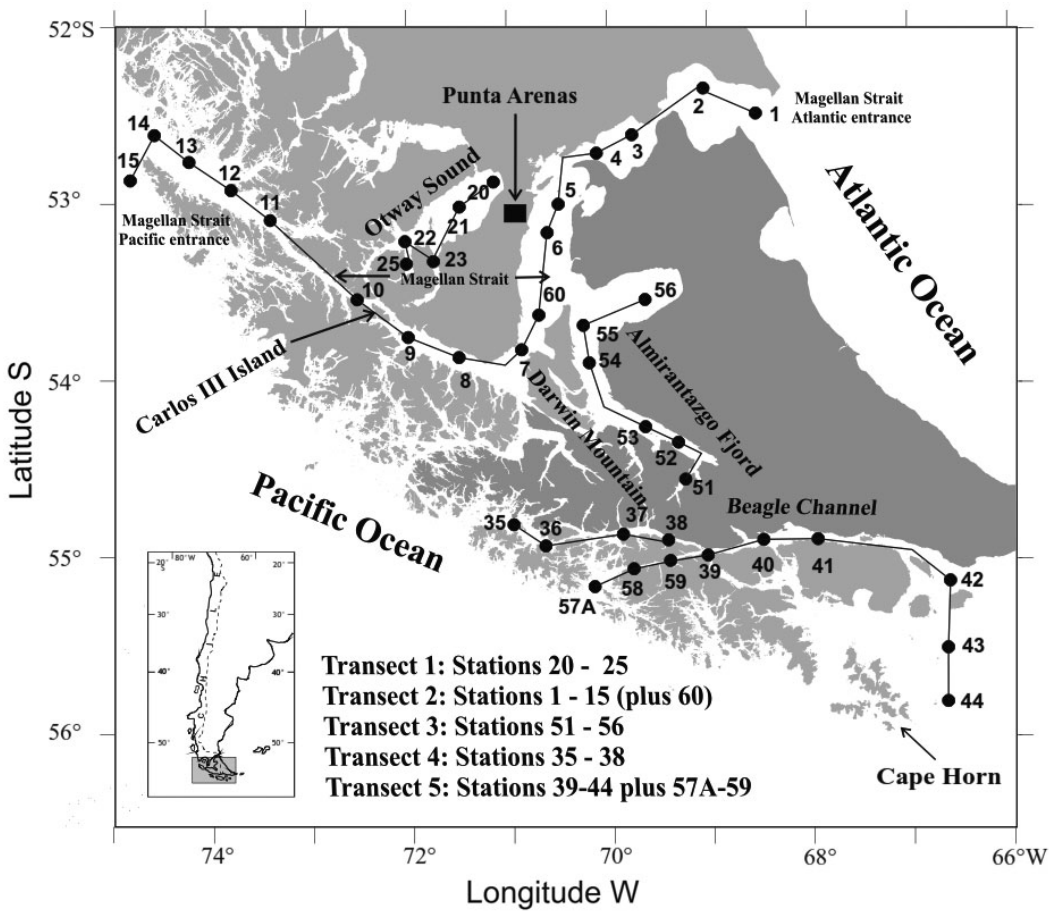

Fig. 1. Study area, showing the stations sampled along 5 different transects (T1-T5) and the process station 21 (located in Otway Sound as part of T1). Segunda Angustura is located between Stns 4 and 5 the fatty acid composition of the key species, Euphausia vallentini, was measured at several stations along the five transects.

\section{Approach 2: A process-oriented time-series station}

Stn $21\left(53^{\circ} 04^{\prime} \mathrm{S}, 71^{\circ} 37^{\prime} \mathrm{W}\right)$, located in the middle of T1 in Otway Sound, was used for a process-oriented study for a period of 3 to $4 \mathrm{~d}$ (Fig. 1). This station was chosen because it represents a typical Patagonian semi-enclosed area affected by freshwater from glacier melt and marine water from the eastern and western sides (see Fig. S1 in the Supplement at www.int-res.com/articles/suppl/m557 p091_supp.pdf). The fate of photosynthetically generated organic carbon through the classical and microbial food webs was studied. In addition to the biological, chemical and physical measurements recorded for the oceanographic stations, we estimated gross primary production (GPP), E. vallentini grazing and vertical particulate matter fluxes.

\section{Approach 1: Five transects of oceanographic stations}

A total of 44 oceanographic stations were distributed along 5 transects located in southern Chilean Patagonia: T1 (Otway Sound), T2 (Magellan Strait between the Pacific and Atlantic Oceans), T3 (Inutil Bay to Almirantazgo Bight), T4 (Cook Bay) and T5 (Beagle Channel to Cape Horn) (Fig. 1). At these stations, water samples for bacterioplankton, phytoplankton and microzooplankton $(1,5,10,25,50 \mathrm{~m}$ depth) and dissolved inorganic nutrient analyses $(1,5,10,25,50$, $75,100,150,200,250,300,350$ and $400 \mathrm{~m}$ ) were collected using a bottle-rosette system equipped with fifteen 10-1 Niskin bottles and a CTD (Seabird 19 CTDO) to determine the physical structure of the water column (temperature, salinity, depth and dissolved oxygen). Salinity and dissolved oxygen sensors were calibrated by measuring salinity (with an Autosal salinometer) and dissolved oxygen (Winkler method) in discrete water samples. At these stations, POC and DOC concentrations as well as size-fractionated chlorophyll a (chl a) were measured. We also determined the abundances and carbon-based biomasses of phytoplankton, bacteria, heterotrophic and autotrophic nanoflagellates (HNF and ANF, respectively), dinoflagellates and ciliates (see below). In addition,

\section{Chl $a$ and phytoplankton analysis}

For chl a determination, $200 \mathrm{ml}$ of seawater was filtered (GF/F Whatman glass fiber filters, $0.7 \mu \mathrm{m}$ nominal pore size) in triplicate and immediately frozen $\left(-20^{\circ} \mathrm{C}\right)$ until later analysis via fluorometry (Turner Design TD-700), using acetone:water (90:10\% v/v) for pigment extraction according to standard procedures (Parsons et al. 1984). Chl a size fractionation was done in 3 sequential steps: (1) for the nanoplankton fraction $(2-20 \mu \mathrm{m})$, seawater $(125 \mathrm{ml})$ was pre-filtered using a $20 \mu \mathrm{m}$ Nitex mesh sieve and then particles were collected on a $2 \mu \mathrm{m}$ Nuclepore filter; (2) for the picoplankton fraction $(0.7-2.0 \mu \mathrm{m})$, seawater $(125 \mathrm{ml})$ was prefiltered using a $2.0 \mu \mathrm{m}$ Nuclepore filter and particles were collected on a $0.7 \mu \mathrm{m}$ GF/F glass fiber filter; and (3) for the whole phytoplankton community, seawater $(125 \mathrm{ml})$ was filtered through a $0.7 \mu \mathrm{m}$ Whatman glass fiber filter. The amount of chl $a$ of the microphytoplankton fraction was obtained by subtracting the chl a values of the nano- and picoplankton fractions from that of the whole plankton fraction. 


\section{Plankton abundance and biomass}

For counting bacterioplankton (pooled bacteria and archaea), protozoans and phytoplankton, 25, 100 and $250 \mathrm{ml}$ of seawater were preserved with a glutaraldehyde $2 \%$ (bacterioplankton) or Lugol's (protozoan and phytoplankton) $1 \%$ final solution. For bacterioplankton abundance (cells $\mathrm{ml}^{-1}$ ), $2 \mathrm{ml}$ of seawater was filtered on polycarbonate membrane filters (Nuclepore $0.2 \mu \mathrm{m}$ ), stained with the fluorochrome DAPI (Porter \& Feig 1980) and counted by epifluorescence microscopy. Bacterial biomass was estimated using a factor of $20 \mathrm{fg} \mathrm{C}$ cell $^{-1}$ (Lee \& Fuhrman 1987). For the enumeration of nanoflagellates, $20 \mathrm{ml}$ seawater from sub-samples were filtered on a $0.8 \mu \mathrm{m}$ polycarbonate membrane filter and stained with Proflavine $(0.033 \% \mathrm{w} / \mathrm{v}$ in distilled water) according to Haas (1982). Sub-samples for diatom counts $(250 \mathrm{ml})$ were preserved in an acidic Lugol's solution (2\% final conc.). Sub-samples of 20 to $50 \mathrm{ml}$ were placed in settling chambers for $30 \mathrm{~h}$ before analysis under an inverted microscope (Zeiss Axiovert 200, 400× magnification) using the standard methodology (Utermöhl 1958); a carbon:plasma volume ratio of $0.11 \mathrm{pg} \mathrm{C} \mathrm{m}^{-3}$ was applied for diatom carbon estimates (Edler 1979).

For counting microzooplankton (dinoflagellates, ciliates and crustacean nauplii), 10 to 301 of seawater from different depths $(0,5,10,25$ and $50 \mathrm{~m})$ were filtered gently through a sieve (10 $\mu \mathrm{m}$ mesh size), then concentrated to a final volume of $\sim 100 \mathrm{ml}$ and preserved with buffered formalin (5\% final concentration). Carbon:plasma volume ratios of 0.30 and $0.19 \mathrm{pg} \mathrm{C} \mathrm{mm}^{-3}$ were used for heavily thecate and athecate dinoflagellate forms, respectively (Gifford \&

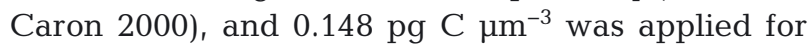
ciliates (Ohman \& Snyder 1991).

Zooplankton samples were collected by oblique tows using a Tucker trawl net $\left(1 \mathrm{~m}^{2}\right.$ catching area, $300 \mu \mathrm{m}$ mesh size) within the upper $75 \mathrm{~m}$ of the water column during day and night sampling. Thus, as euphausiids perform daily migration, their abundance data should be treated with care because they represent a mean of integrated day and night distributions. Samples were preserved in borax buffered formalin (10\% final concentration) for later species and stage identification and counting of euphausiids.

\section{POC, DOC, stable isotopes and nutrients}

Water samples for the determination of POC concentrations including $\delta^{13} \mathrm{C}$ were collected at some se- lected oceanographic stations. The samples $(0.5$ to 1.0 l) were filtered through GF/F filters (pre-combusted for $4 \mathrm{~h}$ at $450^{\circ} \mathrm{C}$ ) and stored frozen in liquid nitrogen until later analysis following standard procedures (von Bodungen et al. 1991). The autochthonous POC was estimated as the sum of the phytoplankton, bacterial and microzooplankton carbon. The carbon estimates were based on carbon to plasma volume ratios. The allochthonous POC $\left(\mathrm{POC}_{\text {alloch }}\right)$ was estimated by using a 2-source-mixing model (Bianchi 2007):

$$
\begin{aligned}
& \% \mathrm{POC}_{\text {alloch }}= \\
& \left(\delta^{13} \mathrm{C}_{\text {sample }}-\delta^{13} \mathrm{C}_{\text {marine }}\right) /\left(\delta^{13} \mathrm{C}_{\text {terrestrial }}-\delta^{13} \mathrm{C}_{\text {marine }}\right)
\end{aligned}
$$

where $\delta^{13} \mathrm{C}_{\text {sample }}$ is the isotopic composition of the sample, $\delta^{13} \mathrm{C}_{\text {marine }}$ is the marine end-member from the most oceanic station (Stn 15, $25 \mathrm{~m}$ depth) and $\delta^{13} C_{\text {terrestrial }}$ is a riverine/lake end-member value for POC as reported by Lafon et al. (2014).

For DOC determination, water samples were filtrated $(0.2 \mu \mathrm{m}$ pore size filters, Swinnex), acidified (300 $\mathrm{\mu l}$ trace metal grade $\mathrm{HCl}$ ) and stored in $40 \mathrm{ml}$ amber I-Chem vials with septum caps. Prior to analysis, DOC samples were bubbled with $\mathrm{CO}_{2}$-free nitrogen for $7 \mathrm{~min}$ to ensure complete removal of dissolved inorganic carbon.

All POC samples were run on an OI Analytical TIC-TOC Analyzer (model 1030). The first run was to determine the organic carbon concentration, the second for the $\delta^{13} \mathrm{C}$ isotope. The TIC-TOC analyzer was interfaced to a Finnegan Mat Delta Plus isotope ratio mass spectrometer for analysis by continuous flow. Data were normalized using internal standards. Analyses were conducted at the G. G. Hatch Isotope Laboratories at the University of Ottawa, Canada (www.isotope.uottawa.ca/techniques/water.html).

For nutrient analyses (nitrate, ortho-phosphate and silicic acid), $50 \mathrm{ml}$ of water sample were stored at $-20^{\circ} \mathrm{C}$ in acid-cleaned high-density polyethylene bottles and analyzed with a nutrient autoanalyzer (Technicon) according to Atlas et al. (1971).

\section{Fatty acid analyses of Euphausia vallentini}

After collection, euphausiids were immediately sorted and measured (total length [TL] in mm from tip of rostrum to end of telson), briefly rinsed with deionized water and stored in liquid nitrogen. Fatty acid analyses were performed according to a slightly modified protocol of Kattner \& Fricke (1986). Briefly, euphausiids were homogenized with a Potter homogenizer and an internal standard (23:0) was added. The lipids were extracted with dichloromethane/ 
methanol $(2: 1, \mathrm{v} / \mathrm{v})$, transesterified to fatty acid methyl esters with $3 \%$ sulphuric acid in methanol. The resulting fatty acid methyl esters were analyzed by gas-liquid chromatography (Hewlett Packard 6890 GC) on a $30 \mathrm{~m}$ wall-coated capillary column (inner diameter $0.25 \mathrm{~mm}$, film thickness $0.25 \mu \mathrm{m}$; liquid phase DB-FFAP). The compounds were identified with standard mixtures and, if necessary, confirmed by mass spectrometry.

\section{Analysis of biological processes}

Nanoflagellate ingestion rate. The bacterivory experiments were performed using the size-fractionation method (Sato et al. 2007, Vargas et al. 2008). Water samples were collected from the fluorescence maximum depth (10 and $15 \mathrm{~m}$ ). Seawater was sizefractioned into 2 fractions by reverse filtration using polycarbonate filters: $<2 \mu \mathrm{m}$ (mostly bacteria and also cyanobacteria) and $<10 \mu \mathrm{m}$ (mostly bacteria, cyanobacteria, HNF and photosynthetic nanoflagellates). Triplicate batch cultures (500 $\mathrm{ml}$ bottles) were incubated on-board for 18 to $20 \mathrm{~h}$ in an incubator rack on deck (with running surface seawater to maintain the ambient water temperature of $1-2^{\circ} \mathrm{C}$ ). Initial control bottles were immediately preserved in glutaraldehyde $(2.0 \% \mathrm{w} / \mathrm{v}$ in $0.2 \mu \mathrm{m}$ prefiltered seawater) for bacteria and nanoflagellate counts. At the end of the incubation period, sub-samples $(20 \mathrm{ml})$ were taken from all bottles and preserved in glutaraldehyde for cell counts. Following Gifford (1993), grazing rates were estimated by comparing prey growth rates in the presence $(<10 \mu \mathrm{m}$ filtered water sample) and absence $(<2 \mu \mathrm{m}$ filtered water sample) incubation bottles. A minimum of 500 bacteria and 100 nanoflagellates were counted per bottle.

Gross primary production estimation rate. Incubations for GPP were performed with water samples obtained from different depths in the photic zone $(2,5,10$ and $25 \mathrm{~m}$ ). Water was transferred into $125 \mathrm{ml}$ borosilicate bottles (gravimetrically calibrated) using a silicone tube. Five control bottles, 5 light bottles and 5 dark bottles were used for each incubation depth. Water samples were collected at dawn and were incubated during the entire light period (average light period was $12 \pm 1.3 \mathrm{~h}$ ). Control bottles were preserved at the beginning of each experiment, while the incubation bottles were attached to a fixed mooring system. Dissolved oxygen concentrations were determined according to the Winkler method (Strickland \& Parsons 1968), using an automatic Metronom burette (Dosimat plus 865) and visual end-point detection. The variation coefficient was $0.03 \pm 0.02 \%$. Rates of GPP were calculated on a per-hour basis and were extrapolated to a daily rate, considering a constant GPP rate during $12 \mathrm{~h}$ natural light period. GPP values were converted from oxygen to carbon using a conservative photosynthetic quotient of 1.25 (Williams \& Robertson 1991). GPP discrete-depth estimates were integrated down to $25 \mathrm{~m}$ ( $1 \%$ light depth), using a polynomial method.

Euphausiid ingestion rate. For E. vallentini grazing estimates, animals were collected by slow vertical hauls in the upper $50 \mathrm{~m}$ of the water column using a WP-2 net (mesh size $200 \mu \mathrm{m}$ ) with a large nonfiltering cod end ( 401$)$ to avoid damage. Undamaged euphausiids were placed in 5-1 acid-washed polycarbonate bottles. These bottles were filled with ambient water with natural food assemblages of microplankton pre-screened through a $200 \mu \mathrm{m}$ net to remove most large grazers. Three control bottles without animals and 3 bottles with 2 to 3 animals each (17-20 mm TL) were placed in an incubator rack on deck (with a top lid maintain a twilight environment) for approximately 19 to $25 \mathrm{~h}$. The seawater incubation was mixed by hand every hour and, to some extent, by the ship's motion. Initial control bottles were immediately preserved with $2 \%$ acidic Lugol's solution, and a subsample was also preserved in glutaraldehyde. At the end of the incubation, sub-samples were taken from all bottles and preserved in glutaraldehyde for nanoflagellate counts $(20 \mathrm{ml})$ and acidic Lugol's solution $(60 \mathrm{ml})$ for counting of the other cells. Ingestion rates, measured as cell removal, were calculated according to Frost (1972), as modified by Marín et al. (1986). Additional experiments to estimate the fecal-string production rate were conducted in parallel using a similar experimental setup, but reducing the incubation time to ca. $2 \mathrm{~h}$. All feces was gently collected, and the carbon content was measured with a CHN elemental analyzer as used for POC measurements.

Carbon flux. The vertical flux of POC was estimated using surface-tethered, cylindrical sediment traps (122 $\mathrm{cm}^{2}$ area and 8.3 aspect ratio) deployed at 50 and $100 \mathrm{~m}$ water depth for periods of 1 to $1.5 \mathrm{~d}$. Sub-samples were taken for microscopic determinations; for POC, 0.5 to 1.01 were filtered, stored frozen and analyzed as described above.

\section{RESULTS}

\section{Hydrological conditions}

The Magellan western zone is characterized by heavy rain, which fluctuates between 2000 and 
$5000 \mathrm{~mm}$ per year, whereas the eastern zone is characterized by light rain, ranging from 200 to $700 \mathrm{~mm}$ per year (Panella et al. 1991). Because the western zone consists mainly of steep, medium-sized islands, it has no watersheds to generate large rivers. According to the Chilean national water administration (DGA 2015), the major local rivers are: Río Grande 1, located on Riesco Island with a mean flow of $18 \mathrm{~m}^{3}$ $\mathrm{s}^{-1}$, draining into Otway Sound; and Río Grande 2, located in Tierra del Fuego Island with a mean flow of $23 \mathrm{~m}^{3} \mathrm{~s}^{-1}$, draining into the Atlantic Ocean. The eastern zone is flat without important rivers (e.g. mean flow $<5 \mathrm{~m}^{3} \mathrm{~s}^{-1}$ ). Therefore, the freshwater supply into the local channels and fjords comes from rain, snow, runoff and glacier melting from the Darwin Mountain Range (see Fig. 1 from Aracena et al. 2015 for a detailed distribution of the location of the Darwin Mountain Range and melt water flow).

\section{Oceanographical conditions}

A conspicuous gradient in temperature $\left(5\right.$ to $\left.8^{\circ} \mathrm{C}\right)$ was found along T2, from the Atlantic to the Pacific entrance to the Magellan Strait. By contrast, at Otway Sound (T1), temperature was almost homothermal, ranging between 6.8 and $7.2^{\circ} \mathrm{C}$ along $\mathrm{T} 1$. The lower temperatures were measured from the Atlantic entrance up to the head of Almirantazgo Fjord (6.0 to $6.5^{\circ} \mathrm{C}$ from Stns 1 to 60 ), and the highest temperature was found in the Pacific Ocean (Stns 14 and 15), close to the western end of Magellan Strait $\left(8.0^{\circ} \mathrm{C}\right.$ ) (Fig. 2).

In the surface layer $(0-50 \mathrm{~m})$ of all transects, salinity ranged from 28 to 33, with the lowest values at the head of Almirantazgo Fjord (Stn 51; Fig. S2 in the Supplement), an area that receives melt water from the Darwin Mountain Range, and the highest values at the western end of Magellan Strait. Dissolved oxygen ranged from 6.0 to $7.5 \mathrm{ml} \mathrm{l}^{-1}$. Nutrients ranged from 0.1 to $12 \mu \mathrm{M}$ (nitrate), 0.4 to $0.8 \mu \mathrm{M}$ (phosphate) and 0 to $4 \mu \mathrm{M}$ (silicic acid), with the lowest values in the Beagle Channel (Fig. 3) and the highest at the western end of Magellan Strait (Fig. 2).

In the deep layer (50 $\mathrm{m}$ to bottom) of all transects, salinity ranged from 30 to 33, being lowest in Almirantazgo Fjord and highest in the western end of Magellan Strait and in Cook Bay. Dissolved oxygen ranged from 5.5 to $7.0 \mathrm{ml} \mathrm{l}^{-1}$, being lowest at the head of Almirantazgo Fjord (Fig. S2) and Balleneros Channel (Fig. S3 in the Supplement) and highest in Cook Bay. Nutrients ranged from 8 to $16 \mu \mathrm{M}$ (nitrate), 0.8 to $1.4 \mu \mathrm{M}$ (phosphate) and 0 to $8.0 \mu \mathrm{M}$ (silicic acid), with the lowest values in the Beagle Channel (Fig. 3) and the highest values at the head of Almirantazgo Fjord (Fig. S2).

\section{Chl $a$ and phytoplankton abundance and composition}

Integrated (upper $25 \mathrm{~m}$ ) chl a concentration averaged $206 \pm 127( \pm \mathrm{SD}) \mathrm{mg} \mathrm{m}^{-2}$, with a maximum value of $411 \pm 153 \mathrm{mg} \mathrm{m}^{-2}$ along $\mathrm{T} 5$, and a minimum of $83 \pm$ $22 \mathrm{mg} \mathrm{m}^{-2}$ along $\mathrm{T} 1$. The chl a biomass was dominated by the large size fraction (microphytoplankton $>20 \mu \mathrm{m}$ ) along all transects (Fig. 4C).

Phytoplankton abundance and composition were recorded along T2 (Magellan Strait) and T5 (Beagle Channel-Cape Horn), where the averaged and integrated phytoplanktonic abundance ranged between 100 and 140000 cells $1^{-1}$ and between 500000 and 4000000 cells $\mathrm{m}^{-2}$, respectively (Fig. 5). Centric diatoms were dominant with $>70 \%$ of the total abundance, while pennate diatoms and autotrophic dinoflagellates contributed considerably only at a few stations in the Magellan Strait and Cape Horn (Fig. 5). The most abundant taxa (mean $\pm \mathrm{SD}$ ) in the Magellan Strait (T2) and Beagle Channel (T5) were represented by the diatom genera Chaetoceros spp. $\left(13700 \pm 16100\right.$ and $57700 \pm 37700$ cells $l^{-1}$, respectively) and Thalassiosira spp. (17700 \pm 13000

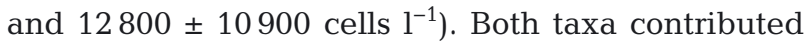
$27 \pm 21 \%$ and $56 \pm 21 \%$ at T2 and $72 \pm 16 \%$ and $14 \pm 7 \%$ at T5 to total diatoms (Fig. 5). Other less abundant taxa (not shown) in the Magellan Strait were the diatoms Thalassionema sp. and Cylindrotheca sp., as well as the seldom-abundant dinoflagellate taxa Protoperidinium spp. and Ceratium spp. In the Beagle Channel area, the diatom Pseudonitzschia spp. and the dinoflagellates Gyrodinium spp. and Ceratium spp. were also observed. The overall POC:chl a ratio was $66 \pm 55$, with a maximum value along T3 $(116 \pm 105)$ and a minimum along T5 (25 \pm 8 ; Fig. 6).

\section{Plankton biomass (bacteria and microzooplankton)}

Integrated (upper $25 \mathrm{~m}$ depth) bacterioplankton carbon biomass showed maximum and minimum integrated values along T1 of $301 \pm 101$ and $169 \pm$ $36 \mathrm{mg} \mathrm{C} \mathrm{m}^{-2}$ and along T2 of 12.1 and $6.8 \mu \mathrm{g} \mathrm{C} \mathrm{l}^{-1}$, respectively. High ANF and HNF biomass were found along $\mathrm{T} 4$, with integrated average concentrations of $9.6 \pm 15.7$ and $25.7 \pm 20.4 \mathrm{mg} \mathrm{C} \mathrm{m}^{-2}$, respectively, and a maximum biomass range of $0-33$ and 

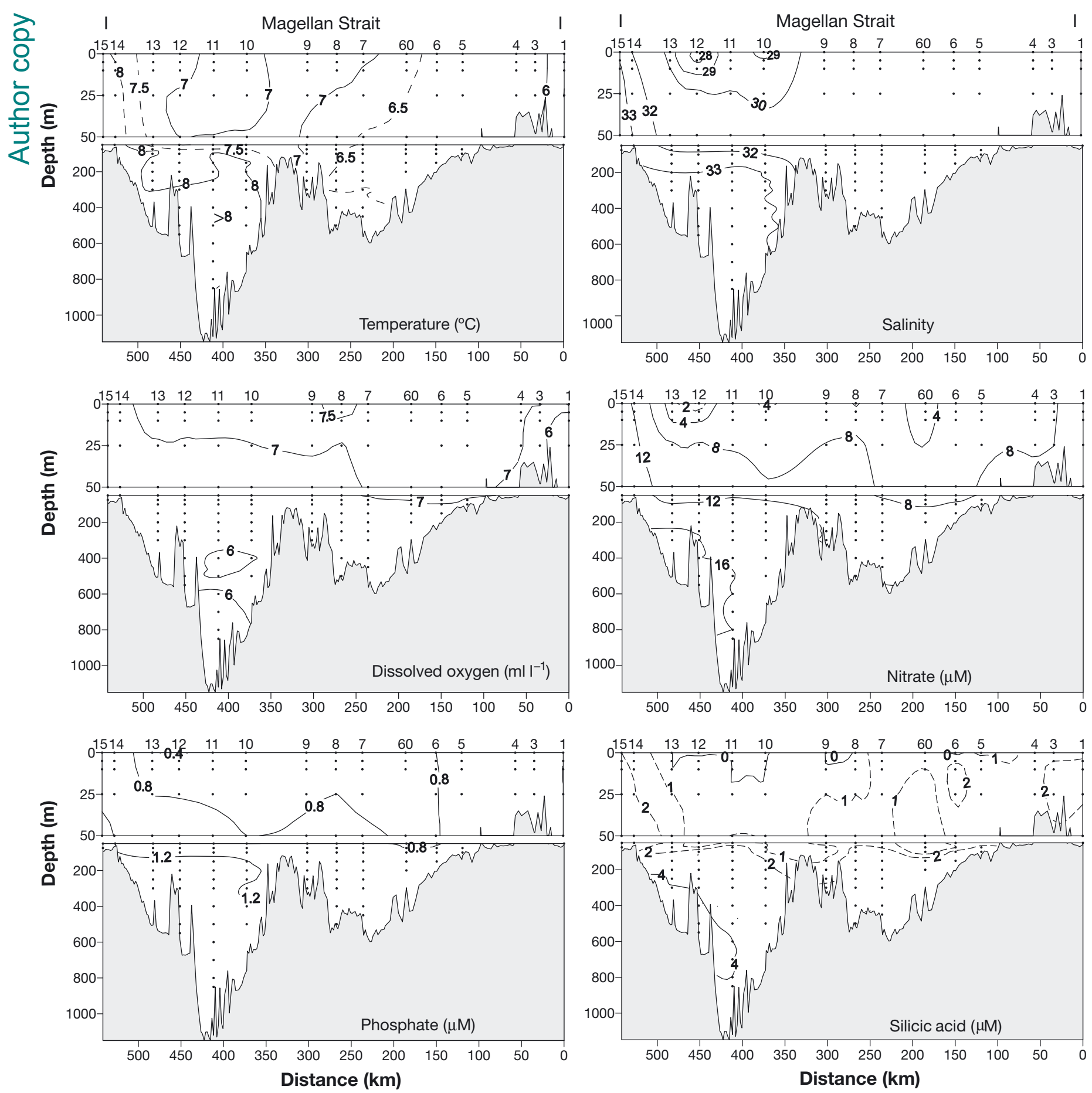

Fig. 2. Vertical distribution of temperature $\left({ }^{\circ} \mathrm{C}\right)$, salinity, dissolved oxygen $\left(\mathrm{ml} \mathrm{l}^{-1}\right)$, nitrate, phosphate and silicic acid $(\mu \mathrm{M})$ along the Magellan Strait transect (T2). Note that the $y$-axis scale changes at $50 \mathrm{~m}$

8-54 mg C m ${ }^{-2}$ for ANF and HNF, respectively. In addition, low biomasses of ANF and HNF were found along T5 and T1, with $0.4 \pm 0.8$ and $9.7 \pm 7.0 \mathrm{mg} \mathrm{C}$ $\mathrm{m}^{-2}$, respectively (Fig. 4E).
Bacterivory by HNF was empirically determined at the chl a maximum depth (10 and $15 \mathrm{~m}$ ) at Stn 21, and averaged between 42 and 77 bacteria $\mathrm{HNF}^{-1} \mathrm{~h}^{-1}$. Considering a mean bacterial carbon value of ca. $20 \mathrm{fg}$ 

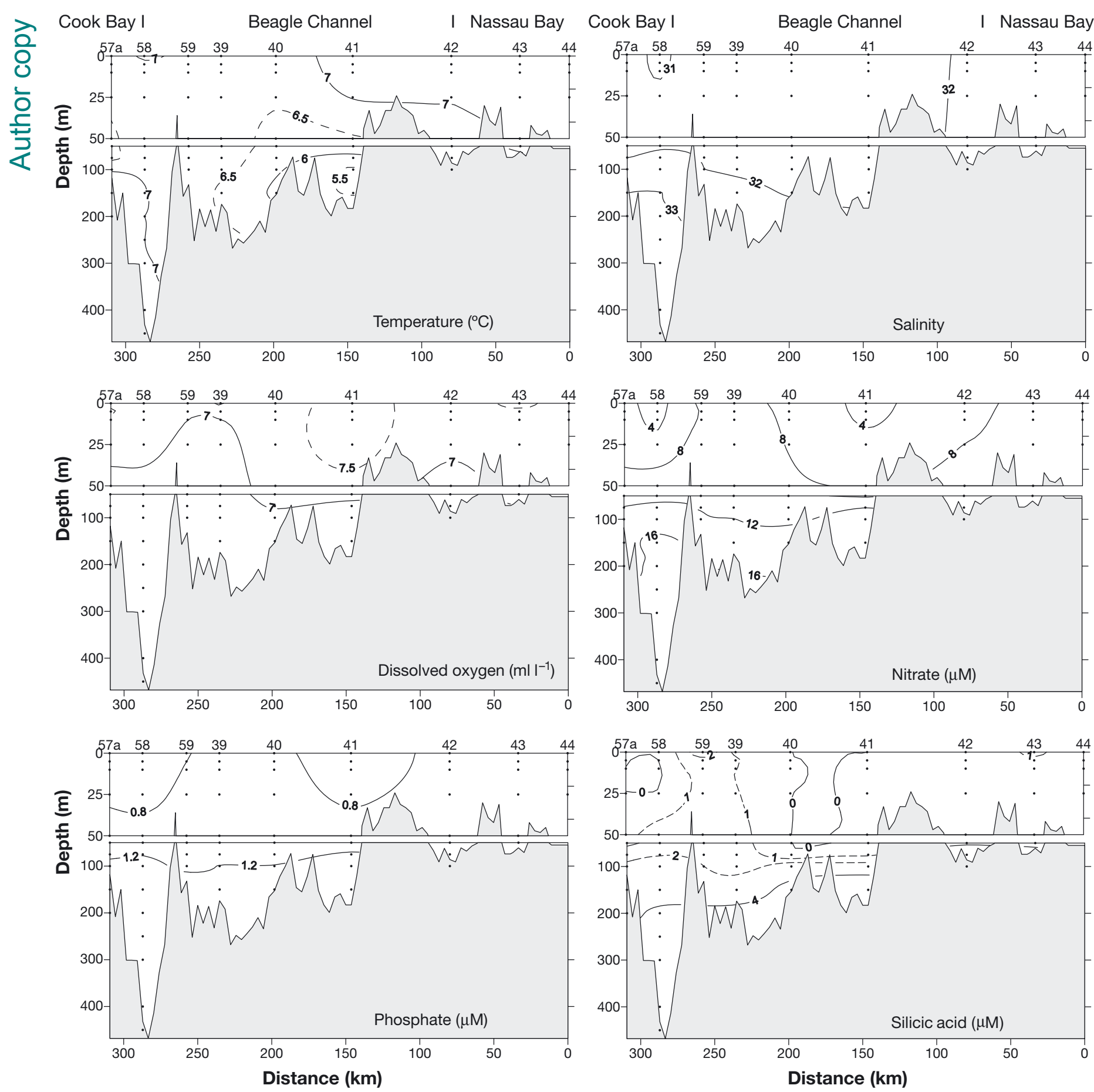

Fig. 3. Vertical distribution of temperature $\left({ }^{\circ} \mathrm{C}\right)$, salinity, dissolved oxygen $\left(\mathrm{ml} \mathrm{l}^{-1}\right)$, nitrate, phosphate and silicic acid $(\mu \mathrm{M})$, along the Beagle Channel to Cape Horn transect (T5). Note that the $y$-axis scale changes at $50 \mathrm{~m}$

C bacteria $^{-1}$ (Lee \& Fuhrman 1987), such a bacterivory rate implies a carbon ingestion rate between 20 and $37 \mathrm{pg} \mathrm{C} \mathrm{HNF}^{-1} \mathrm{~d}^{-1}$.

Heterotrophic dinoflagellates, tintinnids, aloricated ciliates and crustacean nauplii were the most important groups of the microzooplankton, with heterotro- phic dinoflagellates being dominant in terms of abundance and carbon biomass. The maximum and minimum average microzooplankton biomass recorded along transects T1 and T3 were $806 \pm 363$ and $381 \pm$ $165 \mathrm{mg} \mathrm{C} \mathrm{m}{ }^{-2}$, respectively (Fig. 4F). We saw the highest biomasses of microzooplankton at Stn 25 


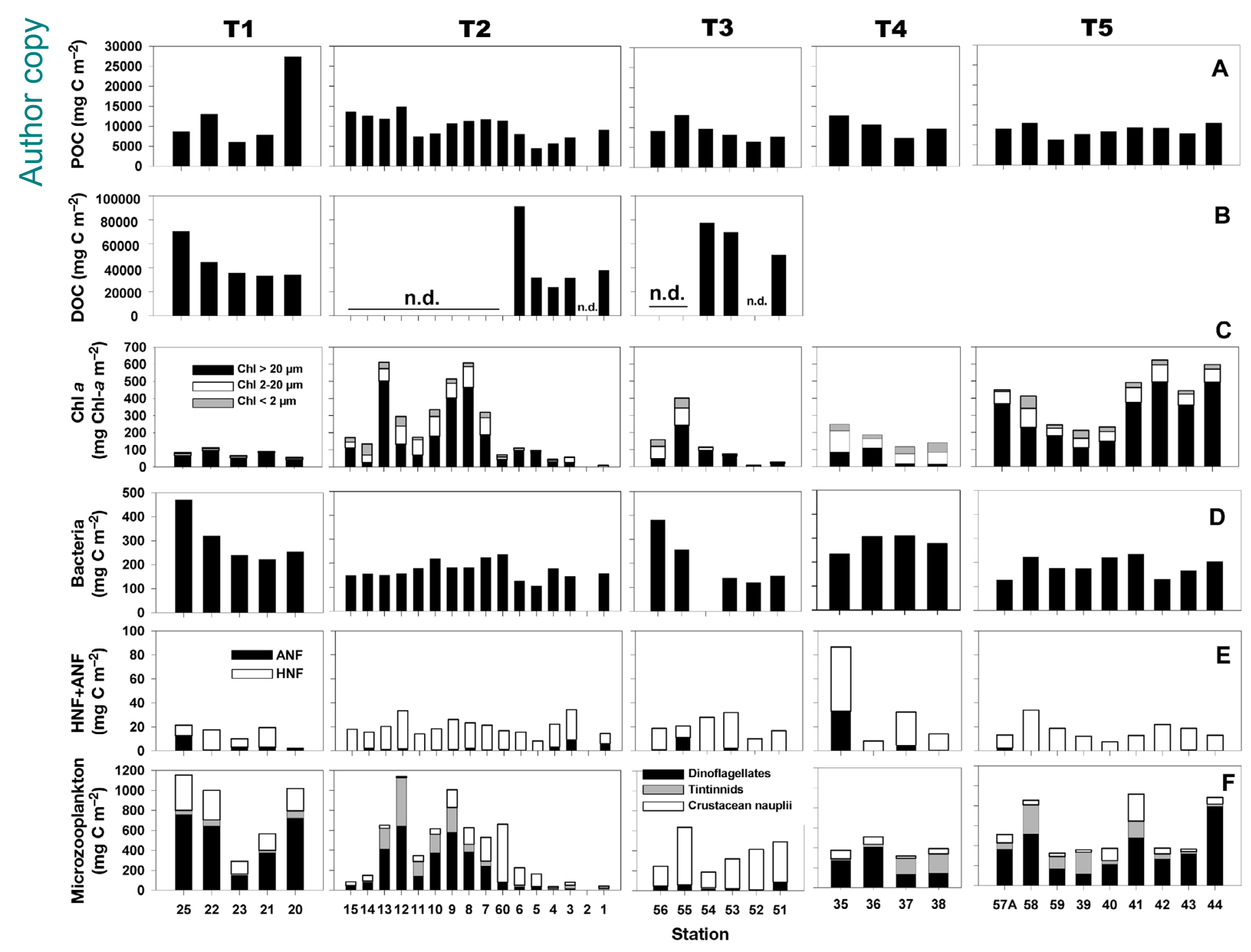

Fig. 4. (A-C) Integrated (upper $25 \mathrm{~m}$ water column) concentrations of (A) particulate organic carbon, (B) dissolved organic carbon and (C) fractionated chlorophyll a (chl a), and (D-F) integrated biomasses of (D) bacteria, (E) heterotrophic and autotrophic nanoflagellates (HNF and ANF, respectively) and (F) microzooplankton functional groups (thecate dinoflagellates, tintinnids and crustacean nauplii) along the 5 transects sampled in Chilean Patagonia. n.d.: not determined

in $\mathrm{T} 1$ (1153 $\left.\mathrm{mg} \mathrm{C} \mathrm{m}^{-2}\right)$, dominated by thecate dinoflagellates, and Stn 12 in T2 (1139 $\mathrm{mg} \mathrm{C} \mathrm{m}^{-2}$ ), dominated by tintinnids and tecate dinoflagellates. Overall, biomasses were lowest at T3 and T4 (average of $391 \mathrm{mg} \mathrm{C} \mathrm{m}^{-2}$ ), and were dominated by nauplii of crustaceans and dinoflagellates, respectively (Fig. 4F).

\section{POC, DOC and stable isotopes}

The integrated POC concentrations showed higher values along T2 $\left(9.8 \pm 3.0 \mathrm{~g} \mathrm{C} \mathrm{m}^{-2}\right)$ and lower values along T5 $\left(8.7 \pm 1.4 \mathrm{~g} \mathrm{C} \mathrm{m}^{-2}\right.$; Fig. $\left.4 \mathrm{~A}\right)$. The total average POC concentration in the upper $25 \mathrm{~m}$ of the water column of the study area was $248 \pm 102 \mu \mathrm{g} \mathrm{Cl}^{-1}$ with a range of 81-773 $\mu \mathrm{C}^{-1}(\mathrm{n}=245)$. DOC showed little spatial variability in concentration along transects $\mathrm{T} 1$ and $\mathrm{T} 2\left(43 \pm 0.3 \mathrm{~g} \mathrm{C} \mathrm{m}^{-2}\right)$, and higher concentrations at T3 $\left(66 \pm 14 \mathrm{~g} \mathrm{C} \mathrm{m}^{-2}\right)$. The average integrated value for the whole study area was $49 \pm 21 \mathrm{~g} \mathrm{C} \mathrm{m}^{-2}$ (or $1.7 \pm 1.0 \mathrm{mg} \mathrm{C} \mathrm{l}^{-1}$; Fig. 4B). A combination of the highest integrated chl a (411 $\pm 152 \mathrm{mg} \mathrm{m}^{-2}$; Fig. 4C) and diatom abundance $\left(79 \pm 47 \times 10^{3}\right.$ cells $^{-1}$; Fig. 5), and lowest POC:chl a ratio $(24 \pm 18)$ occurred at T5 (Fig. 6). 


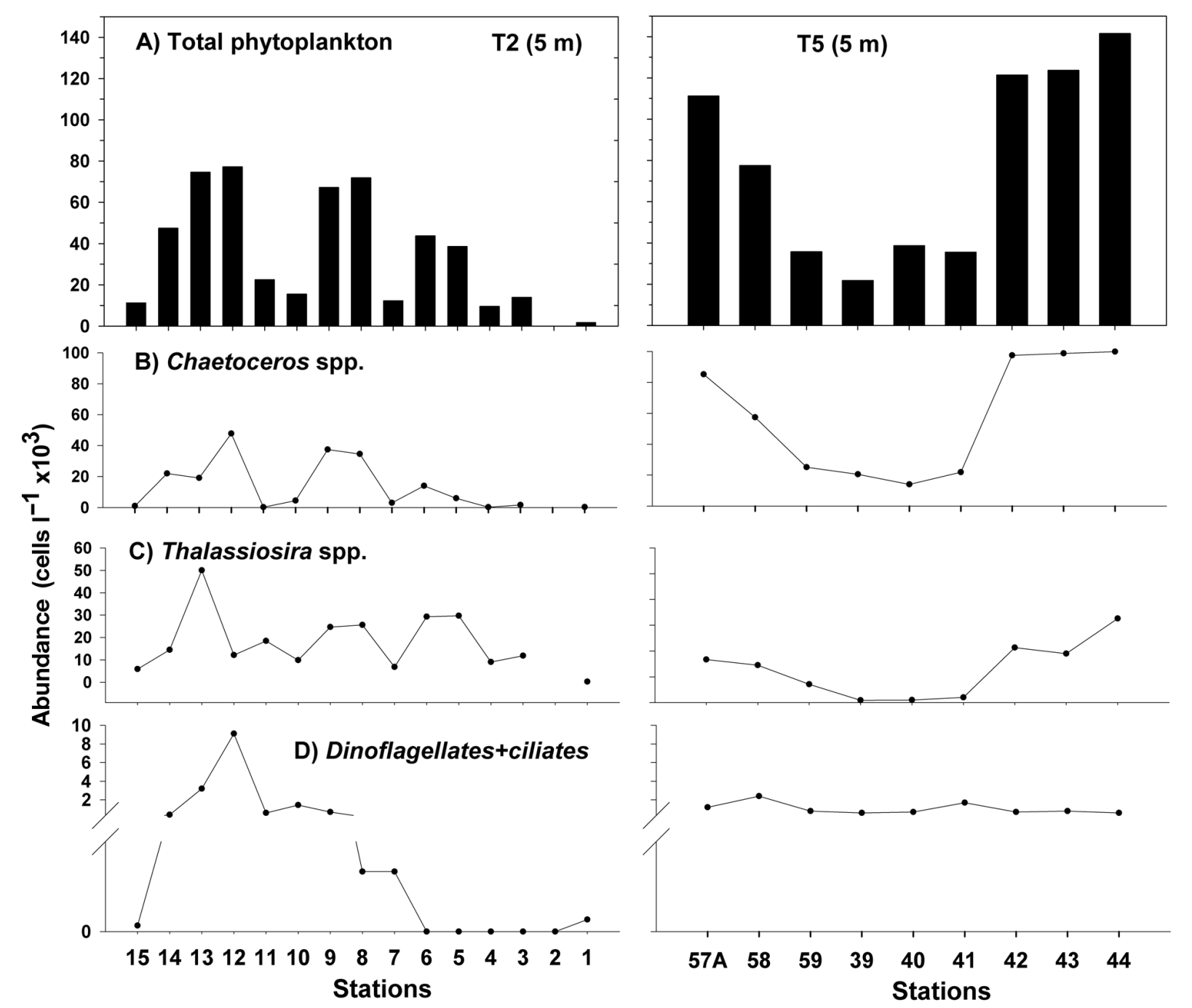

Fig. 5. (A) Total phytoplankton abundance at $5 \mathrm{~m}$ depth in thousands of cells per liter, and (B-D) the contribution of the $3 \mathrm{most}$ important functional groups: species of the genera Chaetoceros (B) and Thalassiosira (C) and total thecate dinoflagellates + ciliates (D) at stations located along the transects of Magellan Strait (T2) and Beagle Channel to Cape Horn (T5)

The largest differences in $\delta^{13} \mathrm{C}$-POC were found at the surface between Stns 13 and 41 , with -18.7 and $-25.8 \%$, respectively, and at $25 \mathrm{~m}$ depth between Stns 35 and 38 , with -18.4 and $-26.0 \%$, respectively (Fig. 7B, Table 1). A clear outsideinside fjord gradient in $\delta^{13} \mathrm{C}-\mathrm{POC}$ was found at Cook Bay (T4), with values most enriched at Stn 35 $(-18.6 \%)$ and most depleted at Stns 37 and 38 $(-24.6 \%)$; at these stations, the relative contribution of allochthonous POC to total POC was on average 14 and $74 \%$, respectively (Table 1 ). Along $\mathrm{T} 1, \delta^{13} \mathrm{C}$ at the surface showed little fluctuation between -22.2 and $-23.4 \%$ from Stns 25 to 20, a region that also encompassed a significant contribution of allochthonous POC to total POC of 49 to $61 \%$ (Table 1).
Along T2, the most enriched value $(-17.1 \%$ ) was found at $25 \mathrm{~m}$ depth of the more oceanic station (Stn 15) on the Pacific Ocean side (used as marine end-member) and the most depleted value was found at Stn $41(-25.8 \%)$ in the inner part of the Beagle Channel. Maximum differences were found at Stns 14 and 10 (25 m depth), where the allochthonous POC contributed 17.8 and $48.4 \%$, respectively. Comparing the outermost stations of all transects on the Pacific Ocean side (Stns 14-15, 35, 57A and 43-44), their $\delta^{13} \mathrm{C}$ values at $25 \mathrm{~m}$ depth remained similarly high between T2 and T4 $(-18.9$ to $18.4 \%$ ) but decreased at the highest latitude stations (Stns 43 and 44$)$ of T5 (-22.0 and $-22.2 \%$; Table 1, Fig. 7B). 
T1
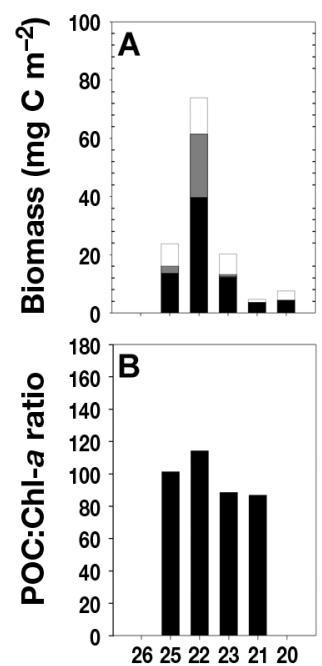

T2



T3
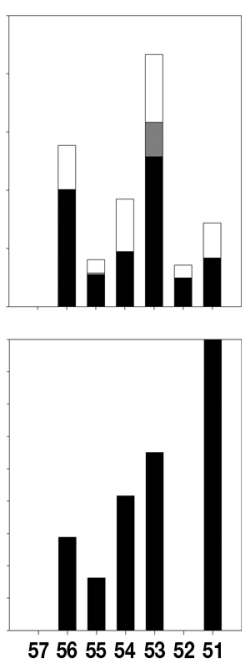

Station
T4
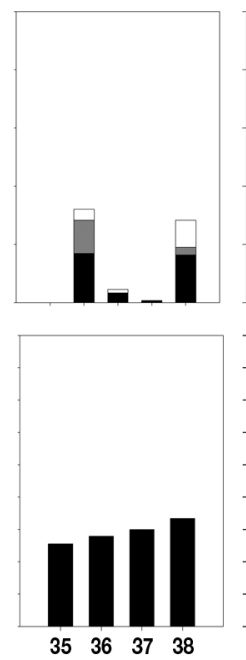

T5

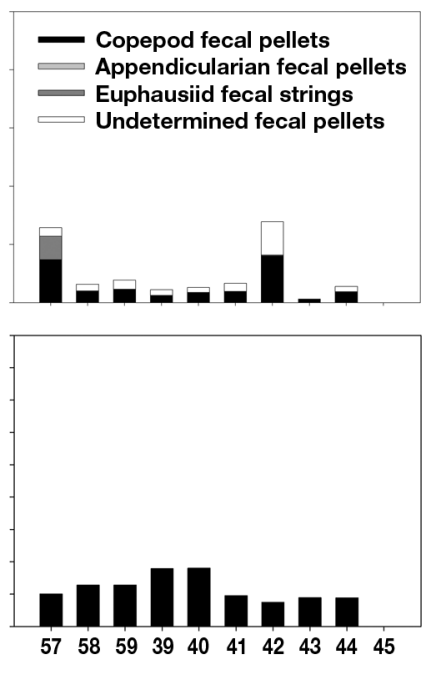

Fig. 6. (A) Integrated carbon-based biomass of copepod, appendicularian, euphausiid and undetermined fecal pellets in the upper $25 \mathrm{~m}$ water column of the stations along the 5 transects. (B) Particulate organic carbon to chlorophyll $a$ ratio at the stations located along the 5 transects. At T3 Stn 51, the POC:chl a ratio bar was truncated and represents a ratio of 296


Fig. 7. (A) Stable isotope $\left({ }^{13} \mathrm{C}\right.$ ) in water samples collected close to the surface (black circles) and at $25 \mathrm{~m}$ depth (white circles) and measured in Euphausia vallentini adults/juveniles tissue (1.8 to $2.0 \mathrm{~cm}$ TL). (B) Average fatty acid ratios in E. vallentini adults/juveniles tissue (1.8 to $2.0 \mathrm{~cm}$ TL) in the 5 transects sampled in the study area. PUFA: polyunsaturated fatty acids;

SFA: saturated fatty acids. Error bars represent 1 SD. n.d.: no data

\section{Abundance, biomass, feeding rates, stable isotopes and fatty acid composition of Euphausia vallentini}

The total abundance of adult E. vallentini ranged from 0.1 to 9.1 ind. $\mathrm{m}^{-3}$ or from 5 to 455 ind. $\mathrm{m}^{-2}$, integrated over the upper $50 \mathrm{~m}$ of the water column
(Fig. 8). The carbon content of individuals from 18 to $22 \mathrm{~mm}$ TL averaged $492 \pm 75 \mu \mathrm{g}$ ind..$^{-1}(\mathrm{n}=63)$. Grazing experiments showed an average ingestion rate of $92 \pm 79 \mu \mathrm{g} \mathrm{C}$ ind..$^{-1} \mathrm{~d}^{-1}$, which is equivalent to $18.6 \%$ of body carbon (daily ration). The average ingestion of heterotrophic (microzooplankton) and autotrophic 
Table 1. Percentage of allochthonous particulate organic carbon $\left(\% \mathrm{POC}_{\text {alloch }}\right)$ in suspended POC along the transects sampled in the southernmost part of Chilean Patagonia. For these estimates, we used the following end-members: Riverine/lake $\left(\delta^{13} \mathrm{C}-27.35\right)$, marine from $\mathrm{Stn} 15$ at $25 \mathrm{~m}$ depth $\left(\delta^{13} \mathrm{C}-17.12\right)$

\begin{tabular}{|c|c|c|c|c|c|}
\hline \multirow[t]{2}{*}{ Transect } & \multirow[t]{2}{*}{ Station } & \multicolumn{2}{|c|}{$\delta^{13} \mathrm{C}$} & \multicolumn{2}{|c|}{$\mathrm{POC}_{\text {alloch }}(\%$} \\
\hline & & $1 \mathrm{~m}$ & $25 \mathrm{~m}$ & $1 \mathrm{~m}$ & $25 \mathrm{~m}$ \\
\hline \multirow[t]{6}{*}{1} & 25 & -22.15 & -21.03 & 49.2 & 38.2 \\
\hline & 22 & -22.24 & -21.68 & 50.1 & 44.6 \\
\hline & 23 & -23.00 & -21.81 & 57.5 & 45.9 \\
\hline & 21 & -22.66 & -21.75 & 54.2 & 45.3 \\
\hline & 20 & -23.36 & -21.39 & 61.0 & 41.8 \\
\hline & Mean $( \pm \mathrm{SD})$ & & & \multicolumn{2}{|c|}{$48.8 \pm 7.1$} \\
\hline \multirow[t]{15}{*}{2} & 1 & -19.60 & -19.09 & 24.3 & 19.3 \\
\hline & 3 & -20.27 & -20.73 & 30.8 & 35.3 \\
\hline & 4 & -21.30 & -21.26 & 40.9 & 40.5 \\
\hline & 5 & -21.23 & -20.63 & 40.2 & 34.3 \\
\hline & 6 & -19.69 & -19.08 & 25.1 & 19.2 \\
\hline & 60 & -21.32 & -21.69 & 41.1 & 44.7 \\
\hline & 7 & -21.02 & -20.12 & 38.1 & 29.4 \\
\hline & 8 & -20.17 & -20.46 & 29.8 & 32.7 \\
\hline & 9 & -21.72 & -20.94 & 45.0 & 37.4 \\
\hline & 10 & -22.08 & -22.07 & 48.5 & 48.4 \\
\hline & 11 & -21.39 & -20.52 & 41.8 & 33.3 \\
\hline & 12 & -19.78 & -20.75 & 26.0 & 35.5 \\
\hline & 13 & -18.77 & -18.43 & 16.2 & 12.8 \\
\hline & 14 & -19.53 & -18.94 & 23.6 & 17.8 \\
\hline & Mean $( \pm \mathrm{SD})$ & & & \multicolumn{2}{|c|}{$31.5 \pm 11.4$} \\
\hline \multirow[t]{5}{*}{4} & 35 & -18.76 & -18.36 & 16.0 & 12.1 \\
\hline & 36 & -22.18 & -22.18 & 49.5 & 56.0 \\
\hline & 37 & -24.63 & -24.29 & 73.4 & 70.1 \\
\hline & 38 & -23.99 & -26.01 & 67.2 & 86.9 \\
\hline & Mean $( \pm \mathrm{SD})$ & & & \multicolumn{2}{|c|}{$53.9 \pm 27.0$} \\
\hline \multirow[t]{10}{*}{5} & $57 \mathrm{~A}$ & -20.68 & -21.96 & 34.8 & 47.3 \\
\hline & 58 & -21.13 & -21.20 & 39.2 & 39.9 \\
\hline & 59 & -22.28 & -22.52 & 50.5 & 52.8 \\
\hline & 39 & -24.84 & -25.01 & 75.5 & 77.1 \\
\hline & 40 & -23.29 & -22.70 & 60.3 & 54.6 \\
\hline & 41 & -25.79 & -20.12 & 84.8 & 29.4 \\
\hline & 42 & -18.79 & -20.10 & 16.4 & 29.2 \\
\hline & 43 & -20.62 & -22.22 & 34.2 & 49.9 \\
\hline & 44 & -19.66 & -19.68 & 24.9 & 25.1 \\
\hline & Mean $( \pm \mathrm{SD})$ & & & \multicolumn{2}{|c|}{$45.9 \pm 19.4$} \\
\hline
\end{tabular}

(phytoplankton) prey was on average 67.4 and $32.6 \%$, respectively. The average fecal-string production rate was $22.5 \pm 11.2 \mu \mathrm{g} \mathrm{C}$ ind ${ }^{-1} \mathrm{~d}^{-1}$, equivalent to $24.5 \%$ of the ingestion rate.

The $\delta^{13} \mathrm{C}$ signals of the euphausiids were very similar along all transects (Fig. 7B). The most depleted value $(-18.5 \%$ ) was found at Stn 21 (process station in the inner Otway Sound) and the most enriched value $(-16.8 \%)$ was found at Stn 35 , located at the Pacific end of T4.

The fatty acid composition of E. vallentini (juvenile and adult individuals) was similar along all transects. Multivariate statistics gave no clear differentiation according to more oceanic or riverine influenced regions. Highest percentages were determined (in descending order) for 16:0 (21-25\%), 20:5(n-3) (23$27 \%), 22: 6(n-3)(12-14 \%), 18: 1(n-9)$ and 18:1(n-7) $(7-11 \%)$ and 16:1(n-7) (5-8\%) (Table 2). A small difference was found between the stations along T3 and the other transects. This was due in particular to higher proportions of 18:1(n-9) and 16:1(n-7) and lower proportions of 20:5(n-3). The proportions of 16:1(n-7), a typical fatty acid of diatoms, were clearly higher in all samples than that of 18:4(n-3), a flagellate marker. The ratio between 18:1(n-9) and 18:1(n-7), indicative of feeding behavior, also showed only small differences, ranging between 1.2 and 1.6. Odd chain-length fatty acids, indicative of bacterial activity, were also minor, with slightly higher values along $\mathrm{T} 2$ and T4.

\section{Productivity, pelagic food web and carbon export flux}

Average GPP rates at Stn 21 showed values of $1.5 \pm$ $0.13 \mathrm{~g} \mathrm{C} \mathrm{m}^{-2} \mathrm{~d}^{-1}$, which was slightly higher than the total microbial community respiration (CR) (1.1 \pm $0.13 \mathrm{~g} \mathrm{C} \mathrm{m}^{-2} \mathrm{~d}^{-1}$ ), resulting in a GPP:CR ratio of 1.4 (autotrophic system). The vertical flux of POC at 50 and $100 \mathrm{~m}$ depth showed values of 73 and $100 \mathrm{mg} \mathrm{m}^{-2}$ $\mathrm{d}^{-1}$, respectively, where the lithogenic and organic matter fraction fluxes were relatively similar, with 204 and $182 \mathrm{mg} \mathrm{m}^{-2} \mathrm{~d}^{-1}$ at $50 \mathrm{~m}$ depth, and 215 and $150 \mathrm{mg} \mathrm{m}^{-2} \mathrm{~d}^{-1}$ at $100 \mathrm{~m}$ depth. The sediment traps collected mainly zooplankton fecal pellets, microphytoplankton and microzooplankton. The dominant type of particles that contributed to the POC flux were zooplankton fecal pellets, with values of 7.9 and $6.3 \mathrm{mg} \mathrm{m}^{-2} \mathrm{~d}^{-1}$ at 50 and $100 \mathrm{~m}$ depth, respectively (Fig. 9), which correspond to $\sim 95 \%$ of the total flux that could be identified by microscopy methods. Fecal pellets from euphausiids, copepods, appendicularians and unidentified, semi-degraded fecal material were recorded, and the amorphous unidentified fecal material predominated with 92 and $97 \%$ at 50 and $100 \mathrm{~m}$ depth, respectively. This type of fecal material corresponds to what we found in the water column in all transects (Fig. 6, upper panels).

\section{DISCUSSION}

The SAAW penetrates the Magellan Strait from the Pacific and Atlantic Ocean sides, although the more prominent sill-constriction at the western side deter- 


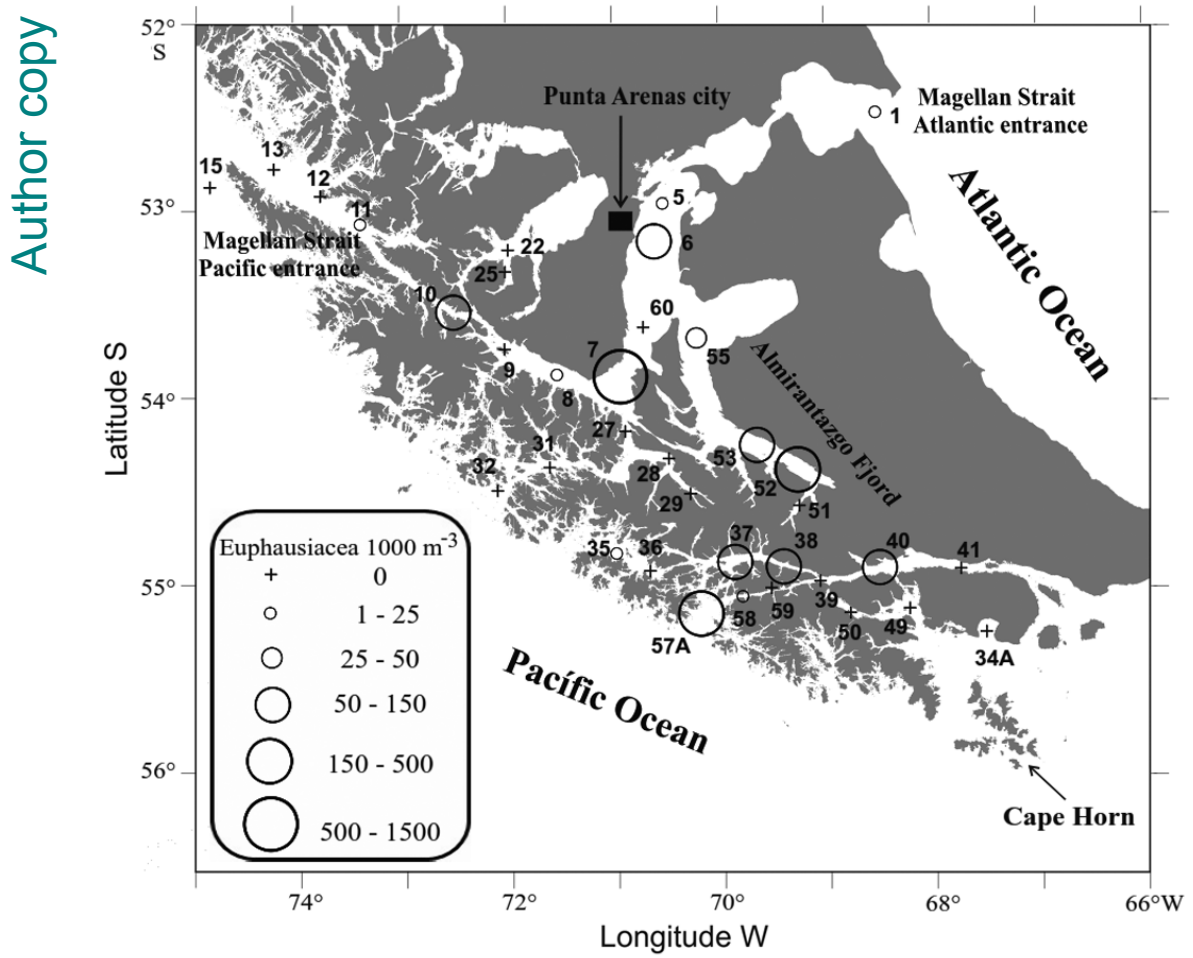

Fig. 8. Average abundance of Euphausia vallentini (ind. per $1000 \mathrm{~m}^{3}$ ) within the study area ern Reloncaví Fjord (200-600 mg C $\mathrm{m}^{-3}$; González et al. 2010).

The composition of POC being on average half allochthonous and half autochthonous, the latter predominated by phytoplankton, suggests a classical spring food web in our study area. The allochthonous and autochthonous proportions were, however, highly variable, in particular along T2, T4 and T5, ranging from 13 to $87 \%$ in the upper water column. The presence of rivers and glaciers usually corresponds to areas with intense allochthonous POM input, as along transects around the Darwin Mountain Range (T3 and inner part of T4). This was also evident in the nearby Chiloé and Aysén channels and fjords, where surface sediments contain up to $50 \%$ of terrestrial material (Sepúlveda et al. 2011, Silva et al. 2011). In central Patagonia, rivers with freshwater discharges close to $1000 \mathrm{~m}^{3} \mathrm{~s}^{-1}$ enter the fjords with a sus- mines a more conspicuous presence of the Pacific SAAW up to the Beagle Channel (Silva \& Palma 2008). In addition, freshwater from glaciers extending all along the Darwin Mountain Range creates an upper $(50 \mathrm{~m})$ brackish layer of slightly modified SAAW (salinity of 31-33) in the oceanic region of the fjords and channels and a heavily modified SAAW (salinity of $<28-31$ ) in the inner regions and areas closer to the Darwin Mountain glacier.

\section{Particulate and dissolved organic matter}

Our average POC concentrations in the upper $25 \mathrm{~m}$ of the water column (248 $\mathrm{mg} \mathrm{C} \mathrm{m}^{-3}$ ) were higher than previous values reported for the Magellan Strait $\left(76 \mathrm{mg} \mathrm{C} \mathrm{m}^{-3}\right.$, Fabiano et al. 1999; $150 \mathrm{mg} \mathrm{C} \mathrm{m}{ }^{-3}$, Povero et al. 1996), but were comparable with those from the north-
Table 2. Euphausia vallentini. Fatty acid composition (mass \% of total fatty acids) averaged for the different transects (T1-T5). Data are means \pm SD. n: number of replicates (specimens from different depth ranges and stations). SFA: saturated fatty acids; PUFA: polyunsaturated fatty acids; MUFA: monounsaturated fatty acids. Asterisk indicates that the data are the sum of several isomers

\begin{tabular}{|lrrrrr|}
\hline & $\mathrm{T} 1(\mathrm{n}=21)$ & $\mathrm{T} 2(\mathrm{n}=14)$ & $\mathrm{T} 3(\mathrm{n}=6)$ & $\mathrm{T} 4(\mathrm{n}=37)$ & $\mathrm{T} 5(\mathrm{n}=28)$ \\
\hline $14: 0$ & $3.3 \pm 0.5$ & $3.0 \pm 0.9$ & $2.9 \pm 0.4$ & $3.6 \pm 0.9$ & $3.0 \pm 0.7$ \\
$16: 0$ & $21.4 \pm 0.7$ & $22.7 \pm 1.6$ & $24.8 \pm 1.6$ & $20.9 \pm 1.1$ & $21.9 \pm 1.4$ \\
$16: 1(\mathrm{n}-7)$ & $7.0 \pm 1.0$ & $5.4 \pm 0.8$ & $8.2 \pm 1.3$ & $6.2 \pm 1.0$ & $5.9 \pm 1.0$ \\
16 PUFA & $4.3 \pm 1.1$ & $4.6 \pm 1.5$ & $2.3 \pm 0.8$ & $3.9 \pm 1.5$ & $4.5 \pm 2.1$ \\
Odd chain FA & $0.2 \pm 0.1$ & $1.5 \pm 1.8$ & $0.3 \pm 0.1$ & $1.6 \pm 1.6$ & $0.6 \pm 0.6$ \\
18:0 & $2.1 \pm 0.3$ & $2.0 \pm 0.3$ & $1.7 \pm 0.8$ & $1.9 \pm 0.3$ & $1.9 \pm 0.4$ \\
18:1(n-9) & $8.1 \pm 1.2$ & $8.6 \pm 1.1$ & $10.5 \pm 1.9$ & $8.7 \pm 1.1$ & $9.1 \pm 1.6$ \\
18:1(n-7) & $6.7 \pm 0.4$ & $5.7 \pm 0.3$ & $6.7 \pm 0.5$ & $6.8 \pm 0.4$ & $6.5 \pm 0.4$ \\
$18: 2(\mathrm{n}-6)$ & $0.9 \pm 0.3$ & $0.8 \pm 0.2$ & $0.7 \pm 0.1$ & $1.3 \pm 0.2$ & $1.0 \pm 0.3$ \\
$18: 3(\mathrm{n}-6)$ & $0.3 \pm 0.1$ & $0.3 \pm 0.1$ & $0.2 \pm 0.1$ & $0.3 \pm 0.0$ & $0.3 \pm 0.1$ \\
18:4(n-3) & $1.0 \pm 0.5$ & $1.6 \pm 0.7$ & $0.9 \pm 0.4$ & $1.3 \pm 0.3$ & $1.0 \pm 0.3$ \\
$20: 1^{*}$ & $0.9 \pm 0.2$ & $0.8 \pm 0.4$ & $1.3 \pm 0.7$ & $1.1 \pm 0.3$ & $1.0 \pm 0.3$ \\
$20: 2(\mathrm{n}-6)$ & $0.2 \pm 0.1$ & $0.1 \pm 0.1$ & $0.1 \pm 0.0$ & $0.1 \pm 0.1$ & $0.0 \pm 0.0$ \\
$20: 4(\mathrm{n}-6)$ & $0.9 \pm 0.3$ & $1.2 \pm 0.8$ & $0.6 \pm 0.3$ & $2.3 \pm 0.4$ & $1.7 \pm 0.5$ \\
$20: 4(\mathrm{n}-3)$ & $0.3 \pm 0.1$ & $0.3 \pm 0.0$ & $0.3 \pm 0.0$ & $0.3 \pm 0.1$ & $0.2 \pm 0.1$ \\
$20: 5(\mathrm{n}-3)$ & $26.5 \pm 1.7$ & $25.4 \pm 2.4$ & $23.3 \pm 3.5$ & $22.9 \pm 1.8$ & $25.2 \pm 1.9$ \\
$22: 1^{*}$ & $0.3 \pm 0.1$ & $0.3 \pm 0.2$ & $0.6 \pm 0.3$ & $0.4 \pm 0.2$ & $0.4 \pm 0.2$ \\
$22: 5(\mathrm{n}-3)$ & $1.3 \pm 0.3$ & $1.1 \pm 0.2$ & $1.1 \pm 0.3$ & $1.1 \pm 0.2$ & $1.0 \pm 0.2$ \\
$22: 6(\mathrm{n}-3)$ & $13.1 \pm 3.1$ & $13.6 \pm 3.7$ & $12.2 \pm 1.8$ & $14.0 \pm 2.2$ & $13.9 \pm 2.1$ \\
& & & & & \\
SFA & $26.7 \pm 1.2$ & $27.6 \pm 2.2$ & $29.4 \pm 1.8$ & $26.4 \pm 1.0$ & $26.8 \pm 1.5$ \\
MUFA & $23.0 \pm 2.1$ & $20.9 \pm 2.0$ & $27.4 \pm 3.6$ & $23.3 \pm 1.2$ & $22.7 \pm 1.4$ \\
PUFA & $49.2 \pm 3.0$ & $49.4 \pm 3.3$ & $42.0 \pm 5.6$ & $48.2 \pm 2.5$ & $49.4 \pm 2.7$ \\
\hline
\end{tabular}




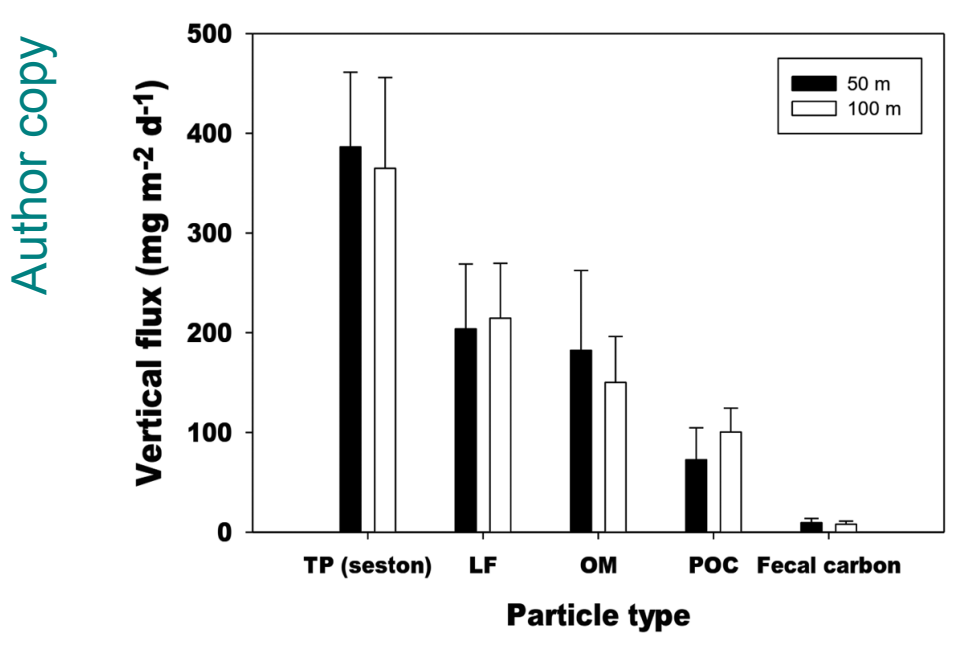

Fig. 9. Total particulate (dry weight) seston (TP), lithogenic fraction $(\mathrm{LF})$, organic matter $(\mathrm{OM})$, particulate organic carbon (POC) and fecal carbon flux as estimated using sediment traps deployed at 50 and $100 \mathrm{~m}$ depth at the process station 21. Error bars represent SD

pended sediment load in the range of $50-100 \mathrm{~g} \mathrm{~m}^{-3}$ and diverse refractory remains, derived from terrestrial vascular plants and forest tree plantations (González et al. 2013). The Magellan Region is devoid of large rivers but is a major glaciered region, which may be an important site of storage and release of organic carbon (Hood et al. 2015). This organic carbon (dissolved and particulate) of allochthonous, mainly glacial origin, and autochthonous, mostly large diatom origin (Turner 2002), seems to set up favorable conditions for the growth of a diverse and abundant microbial community (Gutiérrez et al. 2015). The average integrated bacterioplankton biomass in our study area was similar to that in the Baker and Aysén fjords at $45.3^{\circ} \mathrm{S}(300 \mathrm{mg}$ $\mathrm{C} \mathrm{m}^{-2}$; González et al. 2011), and nearly half of what was found in the Reloncaví Fjord at $41.4^{\circ} \mathrm{S}$ (507 mg C $\mathrm{m}^{-2}$; González et al. 2010).

The high abundance of HNF and its high bacterivory rate resulted in a removal rate of 50 to $92 \mathrm{mg} \mathrm{C}$ of the total bacterioplankton by the HNF community per day, which corresponds to a loss of 24 to $44 \%$ of its biomass. Hence, it may be possible that the impact on bacterial production by the HNF bacterivory results in more autochthonous and allochthonous organic carbon from riverine DOC remains in the water column. This DOC may be available to lower trophic levels during winter, when phytoplankton growth is scarce, and then further carrying the terrestrial signal to higher trophic levels (Vargas et al. 2011), although several trophic flows and losses might obscure the signal up to euphausiids (Fig. 10).
The variability of the POC:chl a ratio was more related to the highly variable chl a than POC concentrations (Fig. 6). The POC:chl a ratio was higher along T3, where the large-size phytoplankton $(>20 \mu \mathrm{m})$ contributed only about one-half to chl $a$, and the minimum was along $\mathrm{T} 5$, where these phytoplankton contributed approximately $3 / 4$ of the ratio. The predominance of the microphytoplankton $(>20 \mu \mathrm{m})$ during this study seems to be a recurrent feature during spring, when the increase in solar radiation and sufficient nutrients seem to favor the development of large, chain-forming diatom blooms (genera Thalassiosira and Chaetoceros) in the northern (González et al. 2011) and southern Patagonian fjords and channels (Iriarte et al. 2001). It is possible that from the Beagle Channel up to Nassau Bay (Stns 40 to 44), the low silicic acid concentration $\left(<1 \mu \mathrm{M}_{i}\right.$ Fig. 3) might represent the aftermath of a diatom bloom because of the high chl $a$ values in the microphytoplankton size fraction in this area (Fig. 4C).

Unexpectedly, low values of phytoplankton abundance and biomass were found at the Pacific and Atlantic entrances of the Strait of Magellan. This may be caused by the strong tidal fluctuation at the entrances (Medeiros \& Kierfve 1988), resulting in a high turbidity (Zingone et al. 2011) and a strong mixing of the water column that together limit the development of phytoplankton (Magazzù et al. 1996). In general, low POC:chl a ratios have been related to productive areas during spring and autumn: for example, a ratio of 87 during early autumn in the Strait of Magellan (Povero et al. 1996), 108 during August-September in the Skagerrak (Maar et al. 2004) or a range of 29-207 in the coastal region off Concepción (Grunewald et al. 2002). By contrast, high values seem to characterize less productive areas during winter or periods when allochthonous organic matter input (probably loaded with refractory humic-like carbon) increases during the spring-summer period with high freshwater and seston (Table S1) inputs from rivers and glaciers, such as at T3 around the Darwin Mountain Range. Other fjord areas, such as the Reloncaví Fjord and the Interior Sea of Chiloé, located in northern Chilean Patagonia, showed low average values during spring (87) and high during winter (487) (González et al. 2010). DOC and POC from freshwater inputs by rivers and glaciers might support benthic (Connolly et al. 2009) and planktonic communities, making stable isotopes $\left(\delta^{13} \mathrm{C}\right)$ a suitable tracer for carbon export from terrestrial systems (West et al. 2006).

In the upper $25 \mathrm{~m}$ of the process study station (Stn 21), the average DOC value was almost 5-fold 


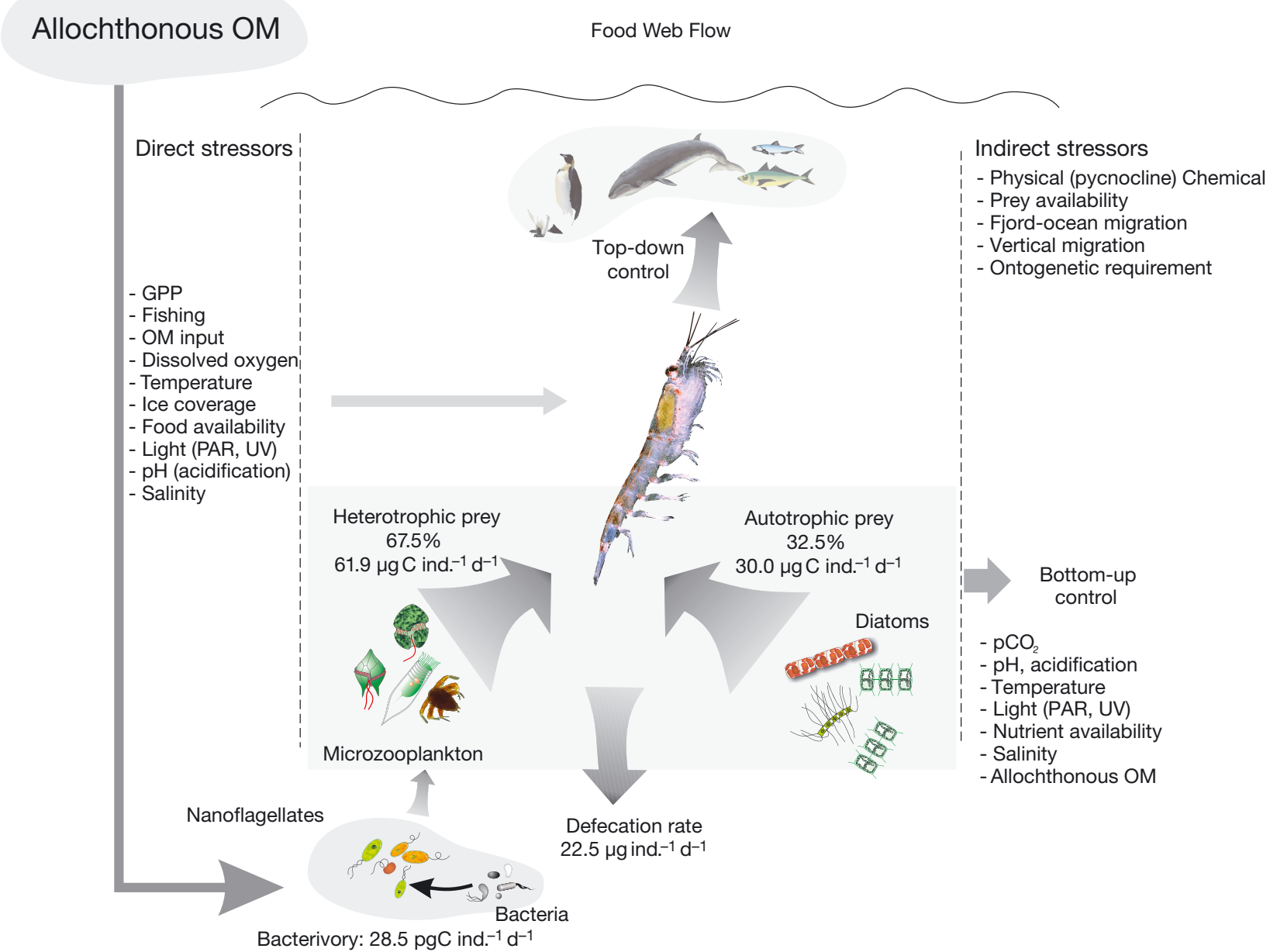

Fig. 10. Trophic flow of E. vallentini in Patagonian fjords. Direct stressors that affect the functional and ecological parameters of the krill and indirect stressors that affect the functional parameters of prey (bottom-up control) and predators (top-down control) are shown. GPP: gross primary production; OM: organic matter; PAR: photosynthetically active radiation; UV: ultraviolet

higher than the POC value. The DOC:POC ratios varied widely at the Atlantic side of the Magellan Strait. The ratio increased from 4.2 at the entrance (Stn 1) to 11.5 at the middle of the strait (Stn 6). While POC showed only little changes, DOC increased considerably towards the inner stations. Thus, we infer that the freshwater at stations close to glaciers (i.e. stations along the T3 in Almirantazgo Fjord) introduce additional DOC to the more autochthonousdominated DOC from the oceanic stations. Smith et al. (2015) hypothesized that fjords from high latitudes might be hotspots of organic carbon input and burial. This supports that the allochthonous input of organic matter into estuarine systems is quantitatively important; however, autochthonous organic matter likely provides more readily available substrates for bacteria (Maranger et al. 2005). Various recent reports suggested that a significant proportion of organic matter in Chilean fjords is of allochthonous origin, which may become available through the microbial food web to higher trophic levels (i.e. allochthonous DOC - bacteria - HNF - zooplankton) (González et al. 2010, 2011, Vargas et al. 2011, Lafon et al. 2014).

\section{Origin and fate of primary production}

Our average values of GPP (Stn 21) during spring were clearly higher than those recorded in late summer for the Magellan Strait (Saggiomo et al. 1994), but similar to estimates for northern Patagonian fjords, such as Reloncaví and Aysén Fjords, highlighting the high productivity of the southernmost part of Chilean Patagonia (González et al. 2010, 2011). High GPP and the dominance of diatoms may result in high vertical POC fluxes. In general, its 
seems that the POC export depends more on the variable input of both particulate and dissolved matter from terrestrial systems (Xing et al. 2011), and, as in coastal regions, is uncoupled from the local GPP.

In the Otway Sound (Stn 21), the total particulate material in the sediment traps at $100 \mathrm{~m}$ depth was composed of $41 \%$ organic matter. The most conspicuous particles in the traps were fecal pellets from copepods and euphausiids. Thus, the high POC concentrations in the water column as well as in the sediment traps suggest that Patagonian fjords may behave as a net sink for organic carbon during the productive season. This is in line with reports that Chilean Patagonia behaves as a carbon export area during the productive period (Sepúlveda et al. 2011, Torres et al. 2011). A study of the carbonate system along the Magellan-Whiteside-Almirantazgo fjord section carried out during our cruise showed low alkalinity and low $\mathrm{pH}$ and high $p \mathrm{CO}_{2}$ levels (C.A.V. unpubl. data). These levels were associated with low salinity waters in the upper $5 \mathrm{~m}$ at Stn 52 in Almirantazgo Fjord, and at Stn 11 (Magellan Strait), mostly associated with the freshwater contribution from ice-melting and/or river runoff. Low $p \mathrm{CO}_{2}$ surface waters $\left(<400 \mu \mathrm{atm}\right.$, which means $\mathrm{CO}_{2}$ undersaturation) were observed mostly along T3 (C.A.V. unpubl. data). This $\mathrm{CO}_{2}$ undersaturation fits well with the dominance of the large microphytoplankon (Fig. 5) and the high carbon export flux found at Stn 21 (Fig. 9). In general, recent studies indicate that high latitude fjords are responsible for approximately $11 \%$ of total modern global organic carbon burial and may play an important role in climate regulation on glacial-interglacial time scales (e.g. Smith et al. 2015).

\section{Euphausiid ecology}

E. vallentini was studied in more detail because it is the predominant euphausiid species in the Patagonian fjord food web and usually accounts for $98 \%$ of total euphausiid abundance in the fjords (Palma \& Silva 2004). Thus, it is an important member of the food web, influencing the overall ecosystem. In addition, other species, such as Thysanoessa gregaria, Nematoscelis megalops, Euphausia lucens, Stylocheiron longicornis and $S$. maximum have been occasionally found in the Magellan Strait (Zagami et al. 2011). The wide range of abundance of $E$. vallentini we found may be caused by diurnal and nocturnal sampling of this species, which performs conspicuous vertical (circadian) migration. Thus, the analysis of grazing impact of euphausiids (and probably also large cope- pods) will be treated as minimum and maximum impacts, and considered with caution because their abundance may have been underestimated during daytime trawls due to the active migration.

E. vallentini showed a moderate daily ratio, which corresponded to $18.6 \%$ of body carbon per day, and the fecal pellet production rate corresponded to $24.5 \%$ of the ingestion rate. In contrast, very high assimilation efficiencies of $42-80 \%$ have been reported for Euphausia superba (Schnack 1985, Pakhomov et al. 1997), which correspond to $35.8 \%$ of defecated (non-assimilated) carbon. This difference may be due to the fact that $E$. vallentini had a higher assimilation efficiency (less defecation) and/or that very small fragments of euphausiid fecal strings were overlooked and not included for fecal carbon estimates. In addition, our grazing experiments showed that E. vallentini removed preferentially heterotrophic prey $(67.5 \%)$ over diatoms $(32.5 \%)$, where the ingested heterotrophic groups were mainly dinoflagellates (thecate and athecate) as well as loricated tintinnids and crustacean nauplii (Fig. 10). The removed phytoplankton comprised mainly centric diatoms such as the genera Rhizosolenia, Chaetoceros and Leptocylindrus. Ontogenetic changes in the diet of $E$. vallentini suggest an increase in carnivory from juveniles to adults, where the percentage of the autotrophic daily ration decreased from $65-100 \%$ to $3-22 \%$ (Gurney et al. 2002). These authors found a predominantly herbivorous and carnivorous feeding behavior for E. vallentini juveniles and adults, respectively, using gut content analysis and stable isotope approaches. Unfortunately, both methods may bias the results as the former technique overestimates the analysis towards hard, mineralskeleton organisms (e.g. diatoms), and the latter only considers the autochthonous versus allochthonous origin of the food ingested.

Although E. vallentini is the predominant member of the euphausiids in this region, the estimated daily grazing impact during the productive season was low, with values up to $3 \%$ of GPP and $0.02 \%$ of the phytoplankton biomass. Estimates of grazing impact exerted by euphausiid in general, and E. vallentini in particular, have been low. When we compare grazing impacts of $E$. vallentini with its congeneric species in sub-Antarctic and Antarctic areas, a similar picture appeared. For example, $0.002 \%$ (daytime sampling) and $0.17 \%$ (nighttime sampling) of the phytoplankton biomass was removed daily by E. vallentini in the Magellan Strait (Hamame \& Antezana 2010), and E. superba had a daily grazing impact of $0.2 \%$ on the phytoplankton standing stock (Atkinson \& Snÿder 
1997) and between 0.1 and $14 \%$ on primary production in the Southern Ocean (Holm-Hansen \& Huntley 1984, Drits \& Semenova 1989, Drits \& Pasternak 1993). In addition, feeding of $E$. vallentini on terrestrial organic carbon, which might be an additional source, could be almost excluded by the carbon isotope signature. Both were clearly different, indicating the presence of terrestrial (allochthonous) carbon in the water column, but only a very low ingestion by $E$. vallentini.

Another way to investigate the diet of E. vallentini is through its fatty acid composition. So far, the lipids of this euphausiid have not been studied. The composition was clearly dominated by the fatty acids belonging to the phospholipids, the major membrane constituents. E. vallentini stores lipids in the form not of wax esters but probably of triacylglycerols, which is comparable to E. superba but different to many other euphausiids and copepods, which also or almost exclusively store wax esters (Falk-Petersen et al. 2000, Lee et al. 2006). Thus, the fatty acid composition of $E$. vallentini (present study) and that of E. superba (Hagen et al. 2001) was dominated by 16:0, 20:5(n-3) and 22:6(n-3). In the older stages of both species, the socalled fatty acid trophic markers 16:1(n-7) for diatoms and 18:4(n-3) for flagellates were not abundant, and thus they are only of limited use to reveal prey preferences. Because the proportions of the 16:1(n-7) fatty acid were clearly higher than those of 18:4(n-3), an ingestion of diatoms seems to be more plausible (Hagen et al. 2001). However, this is in contrast to our experimental results, which showed that E. vallentini ingested more heterotrophic prey (mainly dinoflagellates) than diatoms. The higher proportions of 18:1(n-9) are indicative of omnivorous and carnivorous feeding (Dalsgaard et al. 2003), probably on tintinnids and larval stages of copepods, which will indeed also influence the fatty acid composition. In addition, the 18:1(n-9) to $18: 1(n-7)$ ratio also suggests a dominance of carnivory (Graeve et al. 1997, Cripps et al. 1999, Mayzaud et al. 1999, Cripps \& Atkinson 2000), as the (n-9) isomer of 18:1 is a common fatty acid in metazoans (Falk-Petersen et al. 2000). The very low abundances of 20:1 and 22:1 fatty acids suggest that herbivorous copepodites and adults of calanoid copepods were not important prey (Hagen et al. 2001). The polyunsaturated fatty acid 22:6(n-3) has also been found to be abundant in fish (anchoveta) eggs (Castro et al. 2010) in times of increased dinoflagellate abundance. The presence of this fatty acid in $E$. vallentini (Table 2) suggests an ingestion of these type of eggs by E. vallentini, similarly to E. mucronata predation on anchoveta eggs in the Humboldt Current off central-northern Chile (Krautz et al. 2007), being an addi- tional reason for fish mortality. In contrast, the fatty acids with a terrestrial signature, such as 18:2(n-6) and 18:3(n-3) (Harwood \& Russell 1984, Dalsgaard et al. 2003), were very minor in E. vallentini, on average less than $1 \%$ (Table 2). The small proportions of odd chain-length fatty acids reveal that bacterial-derived material had no influence on the lipids of E. vallentini, and hence is not an additional food source.

The fatty acid composition confirms that in this type of fjord, subjected to a large freshwater and terrestrial input from rivers and glaciers, allochthonous detritus is weakly linked with the local pelagic food web. This situation has been found in different types of rivers and estuaries worldwide (Müller-Solger et al. 2002, van den Meersche et al. 2009, Delong \& Thorp 2006, Martineau et al. 2004, Sobczak et al. 2005). The weak terrestrial signal in euphausiids, using stable isotopes and fatty acid fingerprints as proxies, probably results from a specific selection of autochthonous carbon prey and/or because terrestrial material is inefficiently consumed by E. vallentini. However, it seems more likely that $E$. vallentini avoids feeding on detrital material in general and on organic matter of terrestrial origin in particular. This results in a very weak flow of terrestrial organic matter towards upper trophic levels (Fig. 10). Even though the interaction between photochemical and biological processes might allow bacterial degradation of terrigenous DOM from the coastal environment (Miller \& Moran 1997), the subsequent flow through the microbial food web only enables a minor percentage to reach medium trophic levels (such as euphausiids). The utilization of autochthonous organic matter as a main food source might be also favored by the reported presence of a pigment thin-layer formation, dominated by diatoms and dinoflagellates, in Otway Sound (Ríos et al. 2016), and the high abundance of microzooplankton (Fig. 4F). The high HNF bacterivory rate, and the important role exerted by heterotrophic dinoflagellates, both as prey for euphausiids (Fig. 10) and as diatom grazers (Carreto et al. 2016), highlights the importance of the microbial food web. In general, because of the high complexity of the food web, more information from integrative studies on end-to-end food web characteristics and organic carbon export in Patagonian fjords and channels is required. In this context, direct and indirect stressors, as well as top-down and bottom-up controls, would affect trophic flow and organic matter export (Fig. 10). The high variability in temporal and spatial physical processes and biological interactions would require a combination of tools and scientific studies to be able to capture that variability. 
Overall, E. vallentini plays an important role in Patagonian fjords and channels, being able to remove a wide range of prey sizes that covers nanoplankton to microzooplankton and phytoplankton (Fig. 10). E. vallentini has been reported as the dominant prey found in guts of a wide range of predators such as myctophid and nothotenid fishes, and also prey for several species of penguins and whales (Perissinotto \& McQuaid 1992, Ridoux 1988, Gibbons et al. 2003, Hucke-Gaete et al. 2004, Hamame \& Antezana 2010). In summary, the trophic role of $E$. vallentini did not differ from that of its congeneric species E. mucronata from the Humboldt Current System of the Eastern South Pacific or from that of E. superba in the Southern Ocean. All of them share the condition of 'key species' because they constitute a major carbon and energy flow from lower to higher trophic levels and are important vehicles of POC flux to deeper layers of the ocean.

Acknowledgements. We thank the entire crew and all scientists of the CIMAR 16-2010 oceanographic cruise. We thank Samuel Soto, Cesar Barrales, Paola Reinoso, Eduardo Menschel and María Inés Muñoz for collaboration during sampling and data analysis. We also thank Eduardo Menschel and Ricardo Giesecke for stimulating discussions on plankton dynamics in Patagonian systems. This study was funded by the project CIMAR16-Fiordos (CONA-C16F 09-10 and CONA-C16F 10-11). Additional support is also acknowledged from FONDAP-IDEAL no. 15150003. MINECON NC120086, IC120019 and the Red Doctoral REDOC.CTA, MINEDUC, also provided supported to C.A.V. during the final preparation of the manuscript.

\section{LITERATURE CITED}

Antezana T (1981) Zoogeography of euphausiids of the South Eastern Pacific Ocean. Memorias del Seminario sobre Indicadores Biológicos del Plancton. UNESCO, Montevideo, p 5-23

> Aracena C, Kilian R, Lange C, Bertrand S and others (2015) Holocene variations in productivity associated with changes in glacier activity and freshwater flux in the central basin of the Strait of Magellan. Palaeogeogr Palaeoclimatol Palaeoecol 436:112-122

Atkinson A, Snÿder R (1997) Krill-copepod interactions at South Georgia, Antarctica, I. Omnivory by Euphausia superba. Mar Ecol Prog Ser 160:63-76

Atlas ES, Hager S, Gordon L, Park P (1971) A practical manual for use of the technicon autoanalyser in sea water nutrient analyses. Technical Report. Department of Oceanography, Oregon State University, OR, p 1-215

Bianchi TS (2007) Biogeochemistry of estuaries. Oxford University Press, New York, NY

Capello M, Castellano M, Cutroneo L, Budillon G and others (2011) The composition and distribution of the particulate matter in the Strait of Magellan (Chile) during 1991 and 1995 Italian campaigns. Polar Biol 34:1335-1347
Carreto JI, Montoya NG, Carignan MO, Akselman R, Acha EM, Derisio C (2016) Environmental and biological factors controlling the spring phytoplankton bloom at the Patagonian shelf-break front: degraded fucoxanthin pigments and the importance of microzooplankton grazing. Prog Oceanogr 146:1-21

Castro LR, Claramunt G, González HE, Krautz MC and others (2010) Fatty acids in eggs of anchoveta Engraulis ringens during two contrasting winter spawning seasons. Mar Ecol Prog Ser 420:193-205

Connolly RM, Schlacher TA, Gaston TF (2009) Stable isotope evidence for trophic subsidy of coastal benthic fisheries by river discharge plumes off small estuaries. Mar Biol Res 5:164-171

Cripps GC, Atkinson A (2000) Fatty acid composition as an indicator of carnivory in Antarctic krill, Euphausia superba. Can J Fish Aquat Sci 57:31-37

Cripps GC, Watkins JL, Hill HJ, Atkinson A (1999) Fatty acid content of Antarctic krill Euphausia superba at South Georgia related to regional populations and variations in diet. Mar Ecol Prog Ser 181:177-188

Czypionka T, Vargas CA, Silva N, Daneri G, González HE, Iriarte JL (2011) Importance of mixotrophic nanoplankton in Aysén fjord (Southern Chile) during austral winter. Cont Shelf Res 31:216-224

Dalsgaard J, St. John M, Kattner G, Müller-Navarra D, Hagen W (2003) Fatty acid markers in the pelagic marine environment. Adv Mar Biol 46:225-340

Delong MD, Thorp JH (2006) Significance of instream autotrophs in trophic dynamics of the Upper Mississippi River. Oecologia 147:76-85

DGA (Dirección General de Aguas) (2015) Balance hídrico de Chile. República de Chile, Santiago, p 24

Drits AV, Pasternak AF (1993) Feeding of dominant Antarctic zooplankton in summer. In: Voronina NM (ed) Pelagic ecosystems of the Southern Ocean. Nauka Press, Moscow, p 342-358 (in Russian)

Drits AV, Semenova TN (1989) Trophic characteristics of major planktonic phytophages from South Shetland Islands region during early spring. In: Ponomareva LA (ed) Complex investigations of the pelagic zone of the Southern Ocean. Shirshov Institute Oceanology Publishers, Moscow, p 66-78 (in Russian)

Edler L (1979) Recommendations on methods for marine biological studies in the Baltic Sea. Phytoplankton and chlorophyll. Balt Mar Biol Publ 5:1-38

> Fabiano M, Povero P, Danovaro R, Misic C (1999) Particulate organic matter composition in a semi-enclosed Periantarctic system: the Straits of Magellan. Sci Mar 63(Suppl 1): 89-98

Falk-Petersen S, Hagen W, Kattner G, Clarke A, Sargent J (2000) Lipids, trophic relationships, and biodiversity in Arctic and Antarctic krill. Can J Fish Aquat Sci 57: 178-191

- Frost BW (1972) Effects of size and concentration of food particles on the feeding behaviour of the marine planktonic copepod Calanus pacificus. Limnol Oceanogr 17: 805-815

Gibbons J, Capella JJ, Valladares C (2003) Rediscovery of a humpback whale (Megaptera novaeangliae) feeding ground in the Strait of Magellan, Chile. J Cetacean Res Manag 5:203-208

Gifford DJ (1993) Protozoa in the diets of Neocalanus spp. in the oceanic subarctic Pacific Ocean. Prog Oceanogr $32: 223-237$ 
Gifford DJ, Caron DA (2000) Sampling, preservation, enumeration and biomass of marine protozooplankton. In: Harris RP, Wiebe PH, Lenz J, Skjoldal HR, Huntley M (eds) ICES zooplankton methodology manual. Academic Press, New York, NY, p 193-221

González HE, Calderón MJ, Castro L, Clement A, and others (2010) Primary production and its fate in the pelagic food web of the Reloncaví Fjord and plankton dynamics of the Interior Sea of Chiloé, Northern Patagonia, Chile. Mar Ecol Prog Ser 402:13-30

González HE, Castro L, Daneri G, Iriarte JL and others (2011) Seasonal plankton variability in Chilean Patagonia Fjords: carbon flow through the pelagic food web of the Aysen Fjord and plankton dynamics in the Moraleda Channel basin. Cont Shelf Res 31:225-243

González HE, Castro L, Daneri G, Iriarte JL and others (2013) Land-ocean gradient in haline strati cation and its effects on plankton dynamics and trophic carbon uxes in Chilean Patagonian fjords $\left(47-50 \mathrm{~S}^{\circ}\right)$. Prog Oceanogr 119:32-47

Graeve M, Kattner G, Piepenburg D (1997) Lipids in Arctic benthos: does the fatty acid and alcohol composition reflect feeding and trophic interactions? Polar Biol 18: 53-61

Grunewald AC, Morales CE, González HE, Silvester C, Castro L (2002) Grazing impact of copepod assemblages and gravitational flux in coastal and oceanic waters off Central Chile during two contrasting seasons. J Plankton Res 24:55-67

Gurney LJ, Froneman PW, Pakhomov EA, McQuaid CD (2002) Diel feeding patterns and daily ration estimates of three subantarctic euphausiids in the vicinity of the Prince Edward Island (Southern Ocean). Deep-Sea Res II 49:3207-3227

Gutiérrez MH, Galand PE, Moffat C, Pantoja S (2015) Melting glacier impacts community structure of Bacteria, Archaea and Fungi in a Chilean Patagonia fjord. Environ Microbiol 17:3882-3897

Haas LW (1982) Improved epi uorescence microscopy for observing planktonic microorganisms. Ann Inst Oceanogr Paris (Nouv Ser) 58:261-266

> Hagen W, Kattner G, Terbrüggen A, Van Vleet ES (2001) Lipid metabolism of the Antarctic krill Euphausia superba and its ecological implications. Mar Biol 139: 95-104

- Hamame M, Antezana T (2010) Vertical diel migration and feeding of Euphausia vallentini within southern Chilean fjords. Deep-Sea Res II 57:642-651

Harwood JL, Russell NJ (1984) Lipids in plants and microbes. George Allen \& Unwin Publishers, London

Holm-Hansen O, Huntley M (1984) Feeding requirements of krill in relation to food sources. J Crustacean Biol 4: 156-178

Hood E, Battin TJ, Fellman J, O'Neel S, Spencer RGM (2015) Storage and release of organic carbon from glaciers and ice sheets. Nat Geosci 8:91-96

Hucke-Gaete R, Osman LP, Moreno CA, Findlay KP, Ljungblad DK (2004) Discovery of a blue whale feeding and nursery ground in southern Chile. Proc R Soc Lond B (Suppl) 271:170-173

Iriarte JL, Uribe JC, Valladares C (1993) Biomass of sizefractionated phytoplankton during the spring-summer seasons in Southern Chile. Bot Mar 36:443-450

> Iriarte JL, Kusch A, Osses J, Ruiz M (2001) Phytoplankton biomass in the sub-Antarctic area of the Straits of Magel- lan $\left(53^{\circ} \mathrm{S}\right)$, Chile during spring-summer 1997/1998. Polar Biol 24:154-162

Kattner G, Fricke HSG (1986) Simple gas-liquid chromatographic method for the simultaneous determination of fatty acids and alcohols in wax esters of marine organisms. J Chromatogr A 361:263-286

Krautz MC, Castro LR, González M (2007) Interactions of two key pelagic species of the Humboldt Current: euphausiid predation on anchoveta eggs estimated by immunoessays. Mar Ecol Prog Ser 335:175-185

Lafon A, Silva N, Vargas CA (2014) Contribution of allochthonous organic carbon across the Serrano River Basin and the adjacent fjord system in Southern Chilean Patagonia: Insights from the combined use of stable isotope and fatty acid biomarkers. Prog Oceanogr 129:98-113

Lee S, Fuhrman J (1987) Relationship between biovolume and biomass of naturally derived marine bacterioplankton. Appl Environ Microbiol 53:1298-1303

Lee RF, Hagen W, Kattner G (2006) Lipid storage in marine zooplankton. Mar Ecol Prog Ser 307:273-306

Maar M, Nielsen TG, Gooding S, Tönnesson K and others (2004) Trophodynamic function of copepods, appendicularians and protozooplankton in the late summer zooplankton community in the Skagerrak. Mar Biol 144: 917-933

Magazzù G, Panella S, Decembrini F (1996) Seasonal variability of fractionated phytoplankton, biomass and primary production in the Straits of Magellan. J Mar Syst 9: 249-267

Maranger RJ, Pace ML, del Giorgio PA, Caraco NF, Cole JJ (2005) Longitudinal spatial patterns of bacterial production and respiration in a large river-estuary: implications for ecosystem carbon consumption. Ecosystems 8:318-330

- Marín V, Huntley ME, Frost B (1986) Measuring feeding rates of pelagic herbivores: analysis of experimental design and methods. Mar Biol 93:49-58

Marino D, Sarno D, Zingone A (1993) Distribution of phytoplankton populations in the Straits of Magellan (February-March 1991). Nat Sc Com Ant, Magellan Cruise, February-March 1991. Data Rep II:65-136

- Martineau C, Vicent WF, Frenette JJ, Dodson JJ (2004) Primary consumers and particulate organic matter: Isotopic evidence of strong selectivity in the estuarine transition zone. Limnol Oceanogr 49:1679-1686

> Mayzaud P, Virtue P, Albessard E (1999) Seasonal variations in the lipid and fatty acid composition of the euphausiid Meganyctiphanes norvegica from the Ligurian Sea. Mar Ecol Prog Ser 186:199-210

Mazzocchi MG, Zagami G, Ianora A, Gugliemo L, Crescenti N, Hure J (1995) Copepods. In: Gugliemo L, Ianora A (eds) Atlas of marine zooplankton, Straits of Magellan. Springer Verlag, Berlin

> Medeiros C, Kierfve B (1988) Tidal characteristics of the Strait of Magellan. Cont Shelf Res 8:947-960

> Miller WL, Moran MA (1997) Interaction of photochemical and microbial processes in the degradation of refractory dissolved organic matter from a coastal marine environment. Limnol Oceanogr 42:1317-1324

Müller-Solger AB, Jassby AD, Muller-Navarra DC (2002) Nutritional quality of food resources for zooplankton (Daphnia) in a tidal freshwater system (Sacramento-San Joaquin River Delta). Limnol Oceanogr 47:1468-1476

> Ohman MD, Snyder RA (1991) Growth kinetics of the omnivorous oligotrich ciliate Strombidium sp. Limnol Oceanogr 36:922-935 
Pakhomov EA, Perissinotto R, Froneman PW, Miller DGM (1997) Energetics and feeding dynamics of Euphausia superba in the South Georgia region during the summer of 1994. J Plankton Res 19:399-423

Palma S, Silva N (2004) Distribution of siphonophores, chaetognaths, euphausiids and oceanographic conditions in the fjords and channels of southern Chile. DeepSea Res II 51:513-535

Panella S, Michellato A, Perdicaro R, Magazzù G, Decembrini F, Scarazzato P (1991) A preliminary contribution to understanding the hydrological characteristics of the Strait of Magellan: austral spring 1989. Boll Oceanol Teor Appl 9:107-126

Parsons TR, Maita R, Lalli CM (1984) Counting, media and preservation. A manual of chemical and biological methods for seawater analysis. Pergamon Press, Toronto

> Perissinotto R, McQuaid CD (1992) Land-based predator impact on vertically migrating zooplankton and micronekton advected to a Southern Ocean archipelago. Mar Ecol Prog Ser 80:15-27

Porter KG, Feig YS (1980) The use of DAPI for identifying and counting aquatic microflora. Limnol Oceanogr 25: 943-948

Povero P, Tucci S, Cisternas M, Capello M, Misic C, Fabiano M (1996) Distribution and composition of suspended particulate matter in the Strait of Magellan. In: Faranda FM, Gugliemo L, Povero P (eds) Nat Prog Ant Res Strait of Magellan Ocean. Cruise March-April 1995, Data Report. G. Lang-Arti Grafique, Genova, p 219-230

Ridoux V (1988) Subantarctic krill, Euphausia vallentini Stebbing, preyed upon by penguins around Crozet Island (Southern Indian Ocean): population structure and annual cycle. J Plankton Res 10:675-690

Rignot E, Rivera A, Cassasa G (2003) Contribution of the Patagonia icefields of South America to sea level rise. Science 302:434-437

Ríos F, Kilian R, Mutschke E (2016) Chlorophyll-a thin layers in the Magellan fjord system: the role of the water column stratification. Cont Shelf Res 124:1-12

Rivera A, Bown F, Wendt A, Bravo C (2012) Recent glacier changes in Southern Chile and in the Antarctic Peninsula. An Inst Patagonia (Chile) 40:39-44

Saggiomo V, Goffart A, Carrada GC, Hecq JH (1994) Spatial patterns of phytoplankton pigments and primary production in a semi-enclosed periantarctic ecosystem: the Strait of Magellan. J Mar Syst 5:119-142

Sato M, Yoshikawa T, Takeda S, Furuya K (2007) Application of the size-fractionation method to simultaneous estimation of clearance rates by heterotrophic flagellates and ciliates of pico- and nanophytoplankton. J Exp Mar Biol Ecol 349:334-343

Schnack SB (1985) Feeding by Euphausia superba and copepod species in response to varying concentrations of phytoplankton. In: Siegfried WR, Condy PR, Laws RM (eds) Antarctic nutrient cycles and food webs. Springer, Berlin, p 311-323

Sepúlveda J, Pantoja S, Hughen KA (2011) Sources and distribution of organic matter in northern Patagonia fjords, Chile $\left(\sim 44-47^{\circ} \mathrm{S}\right)$ : a multi-tracer approach for carbon cycling assessment. Cont Shelf Res 31:315-329

Silva N, Palma S (2008) Progress in the oceanographic knowledge of Chilean interior waters, from Puerto Montt to Cape Horn. Comité Oceanográfico Nacional - Pontificia Universidad Católica de Valparaíso, Valparaíso
Silva N, Vargas CA, Prego R (2011) Land-ocean distribution of allochthonous organic matter in surface sediments of the Chiloé and Aysén interior seas (Chilean Northern Patagonia). Cont Shelf Res 31:330-339

Smith RW, Bianchi TS, Allison M, Savage C, Galy V (2015) High rates of organic carbon burial in fjord sediments globally. Nat Geosci 8:450-453

Sobczak WV, Cloern JE, Jassby AD, Cole BE, Schraga TS, Arnsberg A (2005) Detritus fuels ecosystem metabolism but not metazoan food webs in San Francisco Estuary's freshwater delta. Estuaries 28:124-137

Strickland JDH, Parsons TR (1968) Determination of reactive nitrite. Bull Fish Res Board Can 167:71-75

Torres R, Pantoja S, Harada N, González HE, and others (2011) Air-sea $\mathrm{CO}_{2}$ fluxes along the coast of Chile: from $\mathrm{CO}_{2}$ outgassing in central northern upwelling waters to $\mathrm{CO}_{2}$ uptake in southern Patagonia fjords. J Geophys Res 116:C09006

Turner JT (2002) Zooplankton fecal pellets, marine snow and sinking phytoplankton blooms. Aquat Microb Ecol 27:57-102

Utermöhl H (1958) Zur Vervollkommnung der quantitativen Phytoplankton-Methodik. Mitt Int Ver Theor Angew Limnol 9:1-39

van den Meersche K, van Rijswijk P, Soetaert K, Middelburg JJ (2009) Autochthonous and allochthonous contributions to mesozooplankton diet in a tidal river and estuary: integrating carbón isotope and fatty acid constraints. Limnol Oceanogr 54:62-74

Vargas CA, Martínez RA, González HE, Silva N (2008) Contrasting trophic interactions of microbial and copepod communities in a fjord ecosystem, Chilean Patagonia. Aquat Microb Ecol 53:227-242

Vargas CA, Martínez RA, San Martin V, Aguayo M, Silva N, Torres R (2011) Allochthonous subsidies of organic matter across a lake-river-fjord landscape in the Chilean Patagonia: implications for marine zooplankton in inner fjord areas. Cont Shelf Res 31:187-201

Vargas CA, Contreras PY, Iriarte JL (2012) Relative importance of phototrophic, heterotrophic, and mixotrophic nanoflagellates in the microbial food web of a river-influenced coastal upwelling area. Aquat Microb Ecol 65: 233-248

von Bodungen B, Wunsch M, Fürderer H (1991) Sampling and analysis of suspended and sinking particles in the northern North Atlantic. AGU Geophys Monogr 63:47-56

West JB, Bowen GJ, Cerling TE, Ehleringer JR (2006) Stable isotopes as one of nature's ecological recorders. Trends Ecol Evol 21:408-414

Williams PJLeB, Robertson JE (1991) Overall planktonic oxygen and carbon dioxide metabolism: the problem of reconciling observations and calculations of photosynthetic quotients. J Plankton Res 13:153-169

Xing L, Zhang H, Yuan Z, Sun Y, Zhao M (2011) Terrestrial and marine biomarker estimates of organic matter sources and distributions in surface sediments from the East China Sea shelf. Cont Shelf Res 31:1106-1115

Zagami G, Antezana T, Ferrari I, Granata A, Sitran R, Minutoli R, Guglielmo L (2011) Species diversity, spatial distribution, and assemblages of zooplankton within the Strait of Magellan in austral summer. Polar Biol 34:1319-1333

Zingone A, Sarno D, Siano R, Marino D (2011) The importance and distinctiveness of small-sized phytoplankton in the Magellan Straits. Polar Biol 34:1269-1284 